\title{
Seismic microzoning of Štip in Macedonia
}

\author{
V.W. Lee ${ }^{\mathrm{a}}$, M.D. Trifunac ${ }^{\mathrm{a}, *}$, B.Đ. Bulajić ${ }^{\mathrm{b}}$, M.I. Manićc,1, D. Herak ${ }^{\mathrm{d}}$, M. Herak ${ }^{\mathrm{d}}$, G. Dimov ${ }^{\mathrm{e}}$, \\ V. Gičev ${ }^{\mathrm{e}}$ \\ a Dept. of Civil Eng., Univ. of Southern California, Los Angeles, CA 90089, USA \\ b Dept. of Civil Eng. and Geodesy, Univ. of Novi Sad, 21000 Novi Sad, Republic of Serbia \\ c Crvena skopska opština 4/1-1, Skopje, Macedonia \\ d Dept. of Geophysics, Faculty of Science, Univ. of Zagreb, Horvatovac bb, 10000 Zagreb, Croatia \\ e Univ. Goce Delčev, 2000 Štip, Macedonia
}

\section{A R T I C L E I N F O}

\section{Keywords:}

Microzonation maps, which include descriptions of site geology and site soil properties

Contribution of a large distant earthquake to the design strong motion amplitudes Computation of seismic hazard for earthquake sources, which follow different attenuation laws

\begin{abstract}
A B S T R A C T
Seismic microzonation maps for Štip (Macedonia) and its surroundings are presented based on the uniformhazard-spectrum (UHS) methodology. Such mapping satisfies the guidelines for performance-based design (PBD), which requires specification of two sets of spectral amplitudes-one for which the structure will remain essentially linear, and the other for which it will undergo a nonlinear response. The UHS method also enables us to include contributions from excitation by large distant earthquakes as well as the simultaneous effects of site geology and site soils. Thus, the maps we present include, in a balanced way, the effects of near and distant large earthquakes, spatial distribution of seismic activity, the site geology, and the site soil properties.
\end{abstract}

\section{Introduction}

Investigations and observations of damage caused by earthquakes and, in particular, of the irregular distribution of such damage, have shown that the observed variations are related to the properties of geologic and soil site conditions. Microzoning maps have been developed, with coefficients that describe these variations in the amplitudes of shaking, and hence, in the design forces $[17,40,46]$. The equivalent horizontal earthquake forces, and the response-spectrum amplitudes for design, are then increased or decreased according to the values of the amplification coefficients defined in the microzoning maps.

The early development of seismic microzoning maps dates back to the former Soviet Union [1] and Japan [17] in the 1930s. On the basis of many observations following earthquakes, guidelines were developed for the prediction of a relative increase or decrease of site intensities (and therefore of the associated peaks of strong motion amplitudes) based on the nature of site geology and surface soil $[9,40]$. Many published seismic microzonation maps from that time resembled the spatial distribution of geological and soil deposits in the area $[18,38,40,46]$. The local spatial variations were first based primarily on site geology $[40,46]$, and later expanded to include the effects of shallow sediment and local soils. Theoretical and observational studies in Japan eventually also included the properties of local site character- istics that were determined through microtremor measurement. After many years of research and development of probabilistic methods for the evaluation of seismic design forces, we are finding that indeed these old methods-which emphasized the site soil and geology-correctly interpreted the important factors influencing the spatial variations in seismic hazard. In this paper, we will show that site geology is indeed important for mapping seismic hazard, and hence should be included in the empirical scaling equations of strong ground motion.

Since the mid-1970s, after the first direct empirical scaling equations of spectral amplitudes started to appear, it became possible to formulate seismic zoning and microzoning in ways that consider the probabilities of earthquake occurrence, the spatial distributions of earthquake sources, the frequency-dependent attenuation of strong motion amplitudes, and the site geologic and soil conditions [22-25,27,33,35,49-59,68-70]. All of this information was expressed in terms of the response spectrum amplitudes $[10,60,71]$. The advantage of this approach has been that it simultaneously considers all of the factors that contribute to the end result in a balanced way, and comparisons with earthquake occurrence in southern California have confirmed the merits of this approach. For example, the seismic microzonation maps based on the uniform hazard method (UHM) $[2,3,26]$ that were calculated and published in 1987 [27] for the Los Angeles metropolitan area, have not been contradicted by any strong

\footnotetext{
* Corresponding author.

E-mail address: trifunac@usc.edu (M.D. Trifunac).

${ }^{1}$ Retired Professor
} 


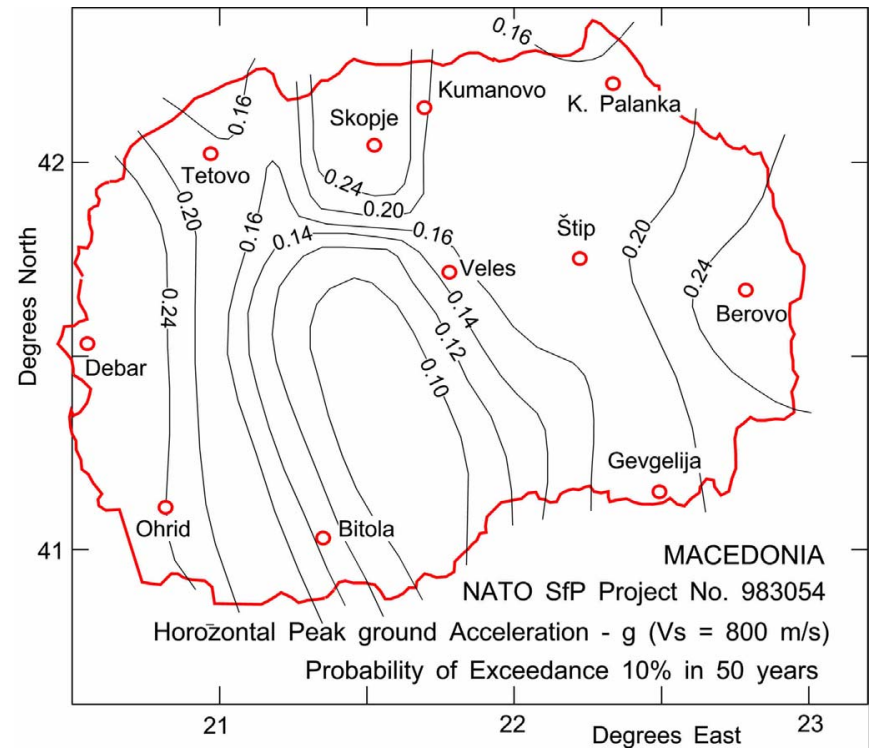

Fig. 1. A preliminary map of peak accelerations (g), at site $\mathrm{A}\left(V_{s} \geq 800 \mathrm{~m} / \mathrm{s}\right)$, for a probability of $10 \%$ exceedance and exposure period of $Y=50$ years (redrawn from [47].

\section{Seismic Hazard Map Macedonia: $A_{\max } \sim \mathrm{PSA}$ for $\mathrm{T}=0.04 \mathrm{~s}-\mathrm{g}$ Probability of Exceedance $=10.0 \%$ in 50 Years}

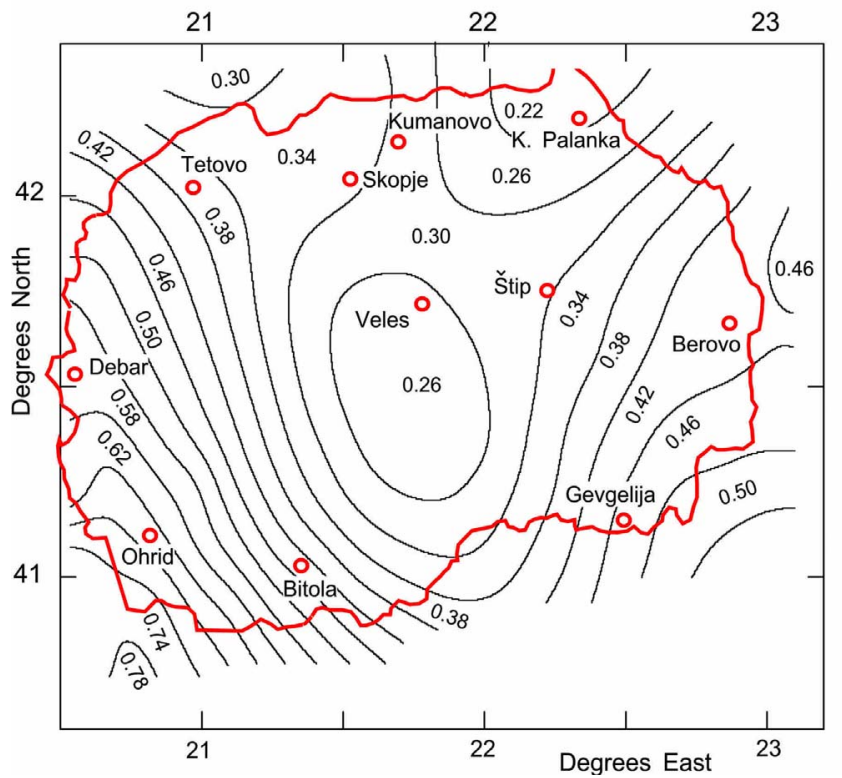

Fig. 2. The upper bound on peak accelerations in terms of $P S A(T)=(2 \pi / T) P S V(\mathrm{~g})$ computed from UHS at $T=0.04 \mathrm{~s}$ and only for local seismicity within $175 \mathrm{~km}$ of the site [35]. Contributions from the Vrancea earthquake source in Romania are not included. Contours are shown for a probability of $10 \%$ exceedance and an exposure period of $Y=50$ years (redrawn from [32]).

motion shaking from the earthquakes that occurred in the area since $1985[58,62]$.

The purpose of this paper is to show, with a specific example, how a model of seismic activity in the region, and including geological site characterization as in Trifunac and Brady [65], can be used to formulate microzoning maps of Štip, Macedonia. The methodology, scaling equations, and descriptions of seismicity used are the same as those described by Lee et al. [33-37], and Lee and Trifunac [31,32] and will not be repeated here. Useful features in this work include (1) that the detailed spatial variations of the geologic site conditions can be integrated directly into the calculation of spectral amplitudes, and as
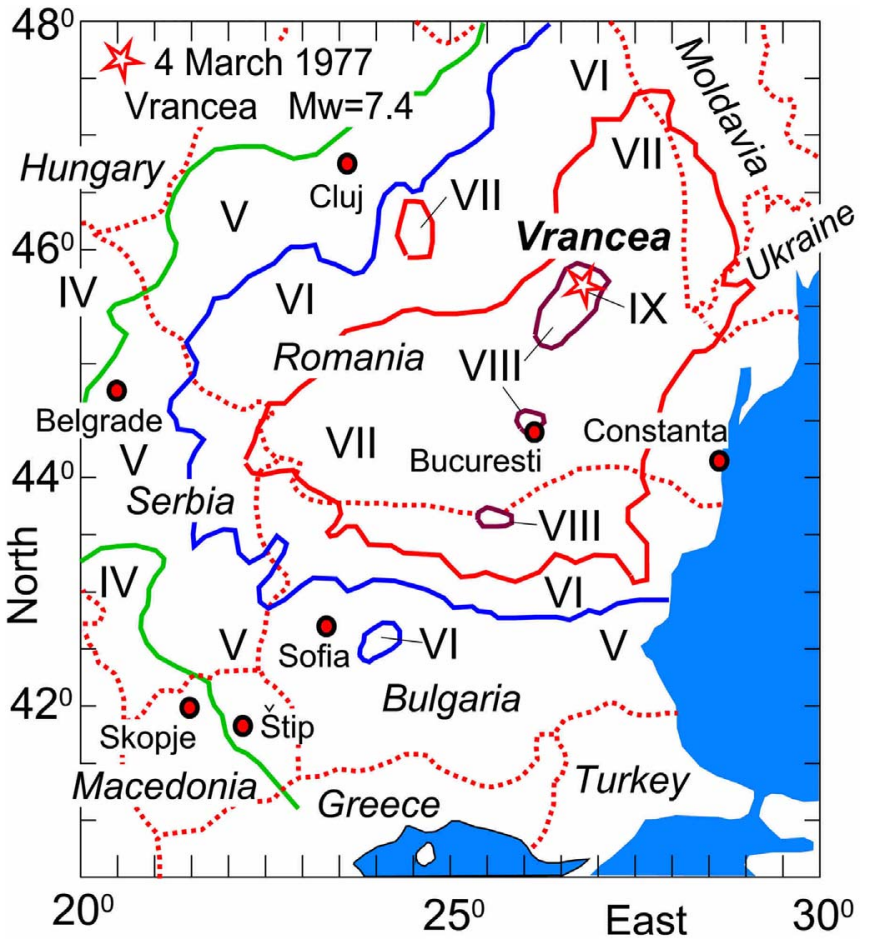

Fig. 3. A map of MSK intensity contours for the March 4, 1977 Vrancea earthquake (extracted from [19] with $M_{w}=7.4, H=98 \mathrm{~km}$, and $I_{0}=$ IX. The Vrancea source zone is centered near $45.88^{\circ} \mathrm{N}$ and $26.98^{\circ} \mathrm{E}$ in Romania, where intermediate and large earthquakes occur at depths between 60 and $200 \mathrm{~km}$. During this 1977 earthquake, in Štip, at an epicentral distance of $598 \mathrm{~km}$, the MKS intensity was V.

will be shown, are one of the significant factors influencing the final result; and (2) that the consequences of contributions from large distant earthquakes (from Vrancea in Romania) can also be included. The differences in the results of such an analysis from the old approach based on probabilistic mapping of only peak ground acceleration will become apparent from what follows.

Fig. 1 shows peak design accelerations for Štip at about $0.18 g$ (for probability of being exceeded at $\mathrm{p}=0.1$ during an exposure period of $\mathrm{Y}=50 \mathrm{yrs}$ ). Fig. 2 shows the analogous seismic hazard map also for the probability of being exceeded a $\mathrm{p}=0.1$ during an exposure period of $\mathrm{Y}=50$ years, calculated by Lee and Trifunac [32]. It gives roughly twice larger peak acceleration in Štip, which is equal to $0.33 g$.

The procedures, which were used for development of the maps shown in Fig. 1 and in Fig. 2 are very different, and thus the results cannot be compared directly. Nevertheless, the end results show differences in peak accelerations of about a factor of two [31,32]. The amplitudes in Fig. 1 are based on scaling for soil site condition A only, while the amplitudes in Fig. 2 are for sites on geological basement rock $(s=2)$, and on "rock" soil sites $\left(S_{L}=0\right)$, and use attenuation equations for scaling PSV spectra based on strong motion recordings in the former Yugoslavia [28,29].

The approach implied for using the peak accelerations in Fig. 1 is that the acceleration at "rock" sites (represented in Fig. 1 by site class A) can be modified to other site classes by an analysis of some models, which are capable of describing amplification of ground motion. This approach does not consider the geological variations surrounding the site. In contrast, in this paper we include site geology via simplified site indicator variables. In several of our previous studies we have argued that describing the site conditions in terms of only surface soil properties in the top $30 \mathrm{~m}$ ( $V_{30}$ or $\mathrm{A}, \mathrm{B}, \mathrm{C}$, and $\mathrm{D}$, for example) does not lead to reliable results and should not be used [30]. We emphasize the same view in this paper. In the following, we will work with the description of site parameters that describe site geology $(s=0,1$, or 2$)$ and site soil properties beyond the depth of $30 \mathrm{~m}\left(S_{L}=0\right.$ and 1) [64]. 
PSA(with Vrancea) / PSA(without Vrancea)

Uniform Hazard Spectra at $T=0.04$ to $2.00 \mathrm{~s}, \mathrm{~s}=2, \mathrm{~S}_{\mathrm{L}}=0$

Probability of Exceedance $=10.0 \%$ in 50 Years
Macedonia

$40^{\circ} 35^{\prime}-42^{\circ} 24^{\prime} \mathrm{N}$

$20^{\circ} 32^{\prime}-23^{\circ} 12^{\prime} \mathrm{E}$

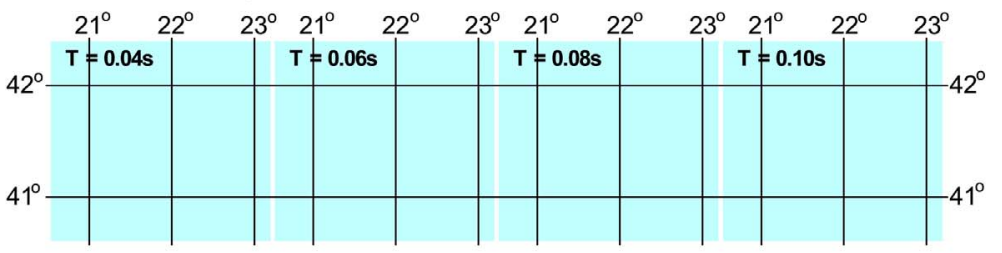

PSV Ratios:

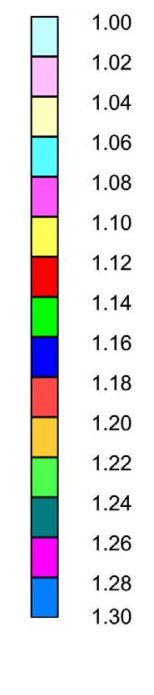

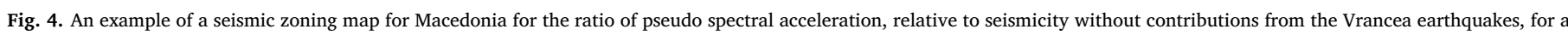

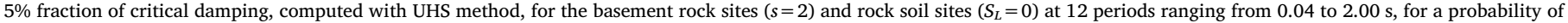
$\mathrm{p}=0.10$ exceedance and an exposure time of $\mathrm{Y}=50$ years (redrawn from [32]).

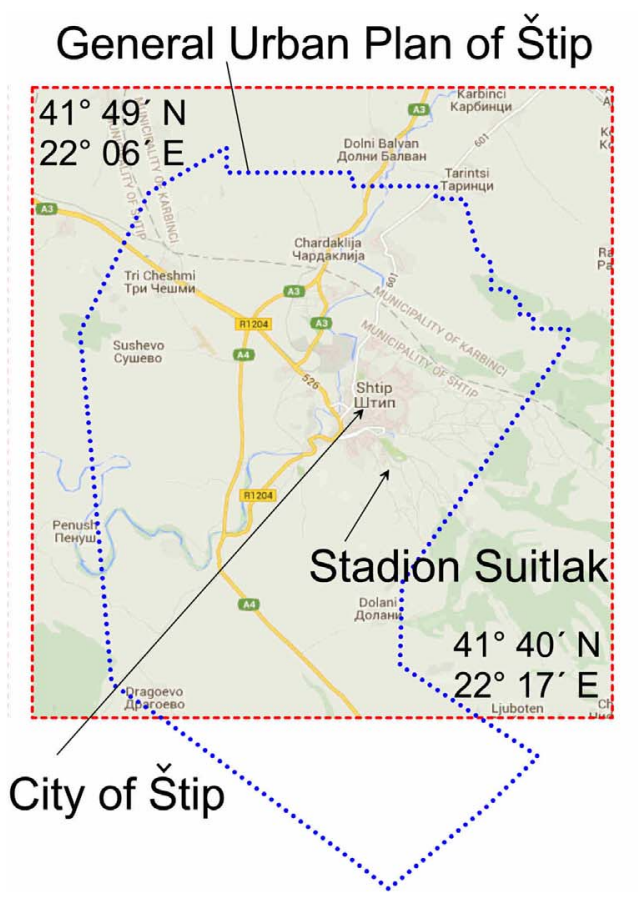

\section{Geological Site Parameters}

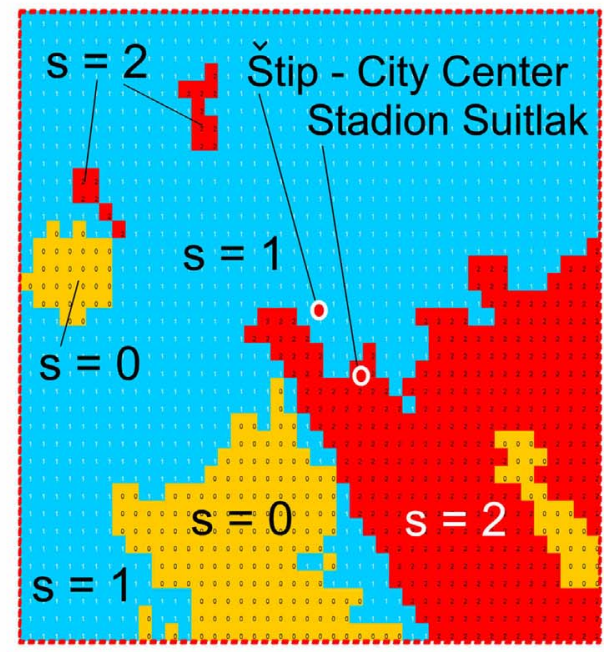

Fig. 5. The general plan of Štip (left) and the geological site parameters ( $=0,1$ or 2 ) in the same area (right).

The development of hazard maps begins with the definition of spatial distribution of seismic sources and their activity in time. The description of this activity, as used in this paper, is briefly outlined in Appendix A. The next step involves the selection of attenuation equations that describe how the desired quantity representing strong ground motion attenuates with distance. The last step combines the contribution of all earthquake sources surrounding the site to compute the distribution functions of the quantity being evaluated and plotting maps showing its spatial distribution.

The performance-based design guidelines in EC8 [6,63] are expressed by the no-collapse and damage limitation requirements. The no- collapse requirement is associated with a large and hence a nonlinear response and the soil-structure system period $T_{\text {nonlinear }}$, while the damage limitation requirement is associated with an essentially linear response and hence a shorter equivalent system period $T_{\text {linear }}$. However, because $T_{\text {nonlinear }}$ and $T_{\text {linear }}$ are associated with different exceedance probabilities, their respective spectral amplitudes cannot be specified with the same fixed shape spectrum and two corresponding peak accelerations. This is because the spectral shape is different for different exceedance probabilities.

Beyond this, we have other concerns that point against using maps, such as that shown in Fig. 1, because the contributions to hazard from 
a

Microzonation Map of Štip - peak accelerations - $g$ Uniform Hazard Spectra - PSA, T= $0.04 \mathrm{~s}, \mathrm{~s}=0,1,2, \mathrm{~S}_{\llcorner}=0$ Probability of Exceedance $p=10.0 \%$ in 10 Years

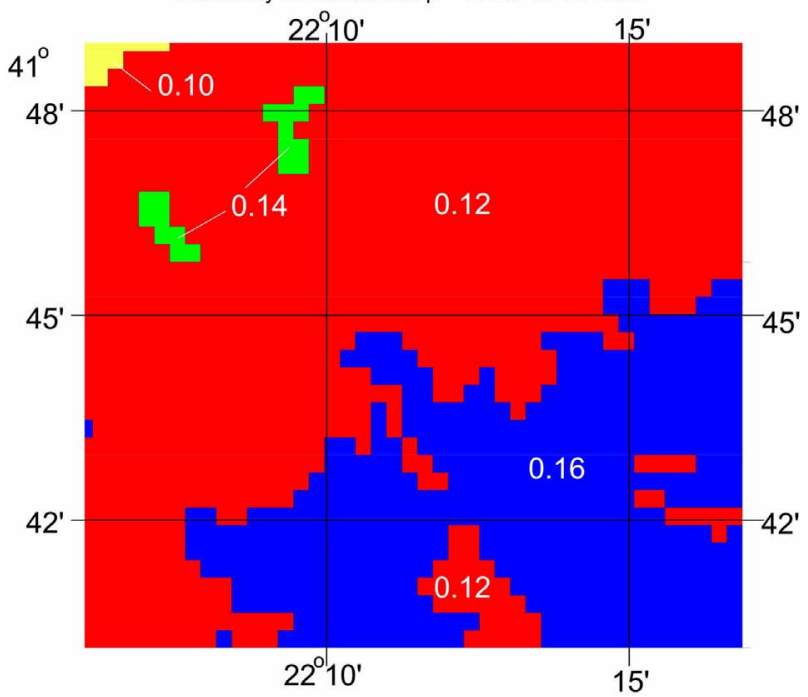

C

Microzonation Map of Śtip - peak accelerations - $g$ Uniform Hazard Spectra - PSA, T=0.04 s, $s=0,1,2, S_{L}=1$

Probability of Exceedance $p=10.0 \%$ in 10 Years

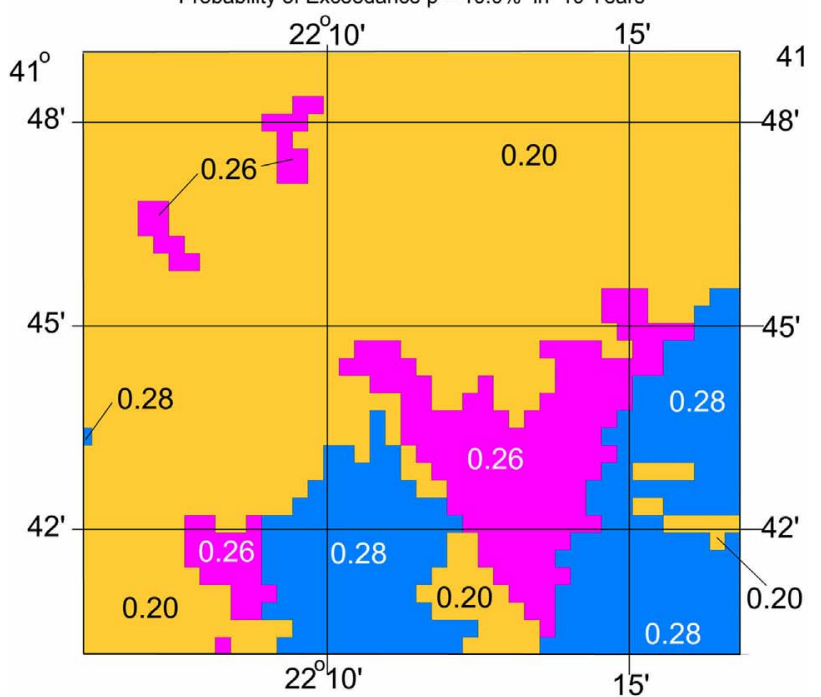

b

Microzonation Map of Štip - peak accelerations - $g$ Uniform Hazard Spectra - PSA, T= $0.04 \mathrm{~s}, \mathrm{~s}=0,1,2, \mathrm{~S}_{1}=0$ Probability of Exceedance $p=10.0 \%$ in 50 Years

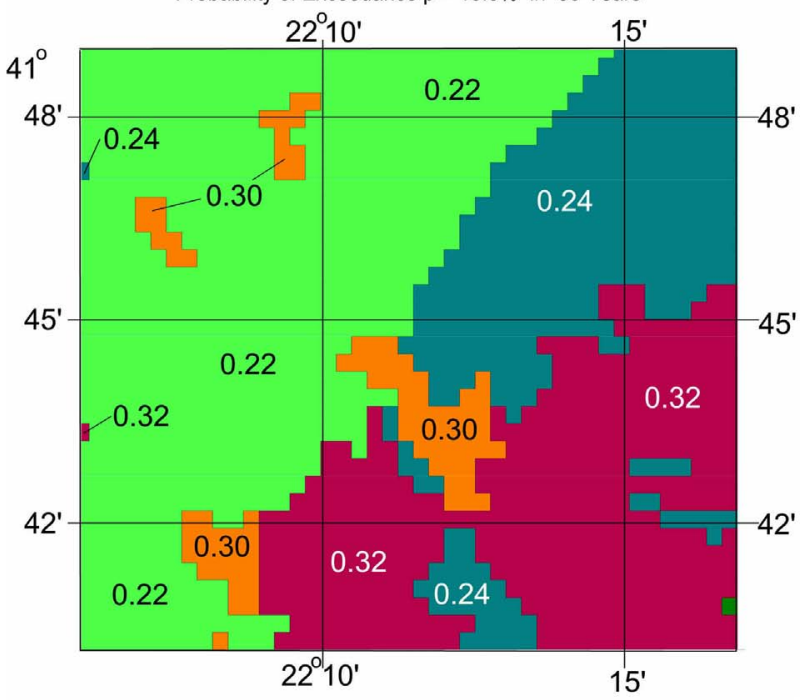

d

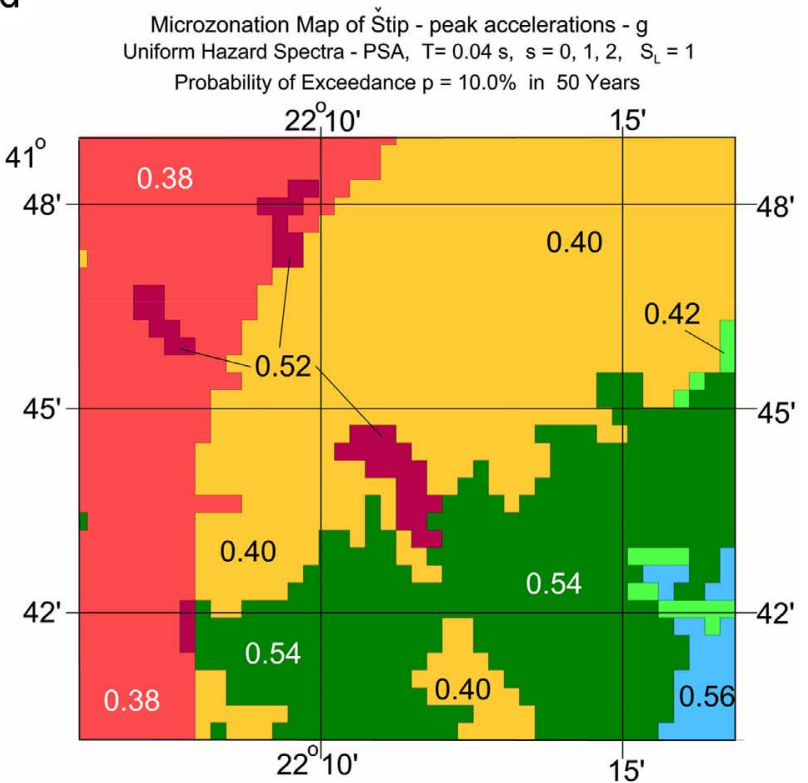

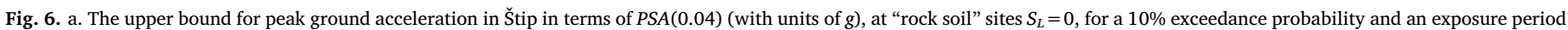

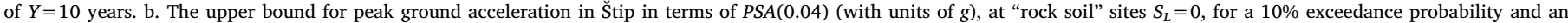

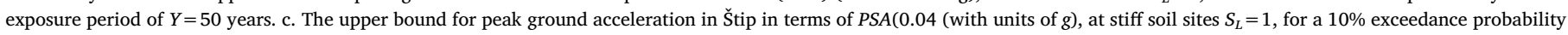

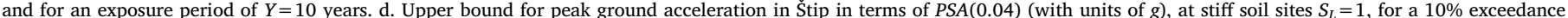
probability and for an exposure period of $Y=50$ years.

the large Vrancea earthquakes (Fig. 3) are not included when scaling of design motions is performed via peak accelerations. The reader will find further discussion about these concerns in Lee and Trifunac [31,32]. We have shown, for example, that the Vrancea earthquakes dominate seismic hazard in eastern Serbia. This domination diminishes with increasing epicentral distance, so that in northern Macedonia it is down to several tens of percents (Fig. 4). In eastern Macedonia, this contribution is even smaller due to active seismicity in nearby Bulgaria [32].

Fig. 4 shows the ratio of spectral accelerations computed with and without contributions of the Vrancea earthquakes. It is seen that in the high-frequency range (higher than about $2 \mathrm{~Hz}$ ), the contribution to spectral accelerations from the Vrancea earthquakes can be neglected for all sites in Macedonia for $\mathrm{p}=0.1$ and $\mathrm{Y}=50$ years. However, as oscillator periods become longer, the contribution of the Vrancea earthquakes increases. At a frequency of $0.5 \mathrm{~Hz}$, in Štip, the Vrancea earthquakes increase spectral accelerations by about $8 \%$.

\section{2. Štip and its surroundings - Geological site classification}

The central city region (CCR) of the city of Štip covers a region that is within the following borders: the Kemer locality and the Otinja River dam on the east, the High Medical School on the south, the spa Kežovica on the west, and the Babi settlement on the north. The geologic deposits in the eastern and northern parts of CCR are sediments predominantly consisting of Eocene sandstone, marl, and conglomerates with layer thicknesses of about $350 \mathrm{~m}$. Precambrian granite is present in the western part of CCR that covers the Novo Selo 
a

Microzonation Map of Stip -with contribution from Vrancea earthquakes Uniform Hazard Spectra - PSA - $g, T=1.0 \mathrm{~s}, \mathrm{~s}=0,1,2, \mathrm{~S}_{\mathrm{L}}=0$ Probability of Exceedance $p=10.0 \%$ in 10 Years

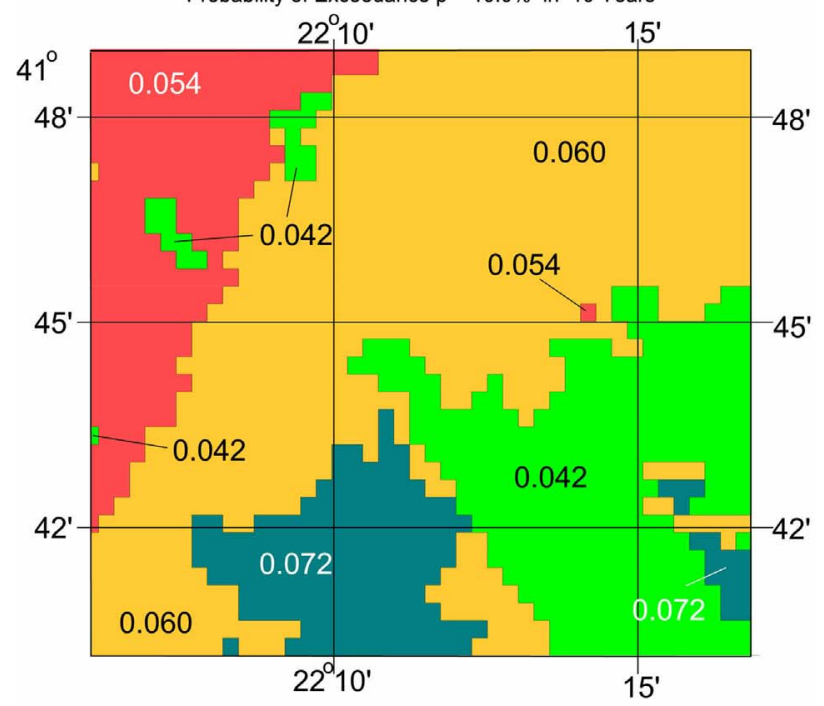

C

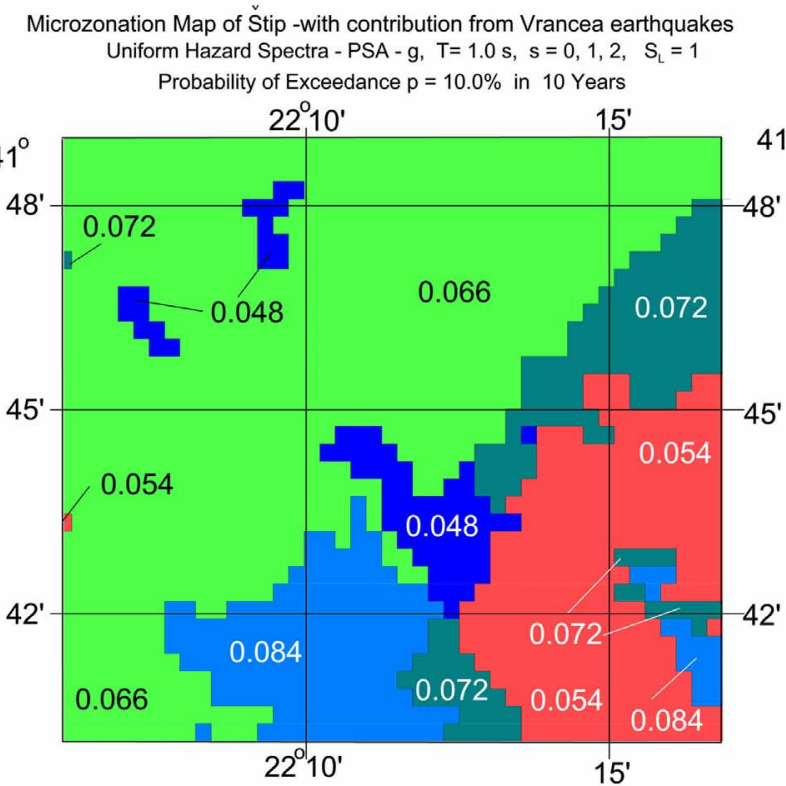

b

Microzonation Map of Štip -with contribution from Vrancea earthquakes Uniform Hazard Spectra - PSA - g, T=1.0 s, $s=0,1,2, S_{\mathrm{L}}=0$ Probability of Exceedance $p=10.0 \%$ in 50 Years

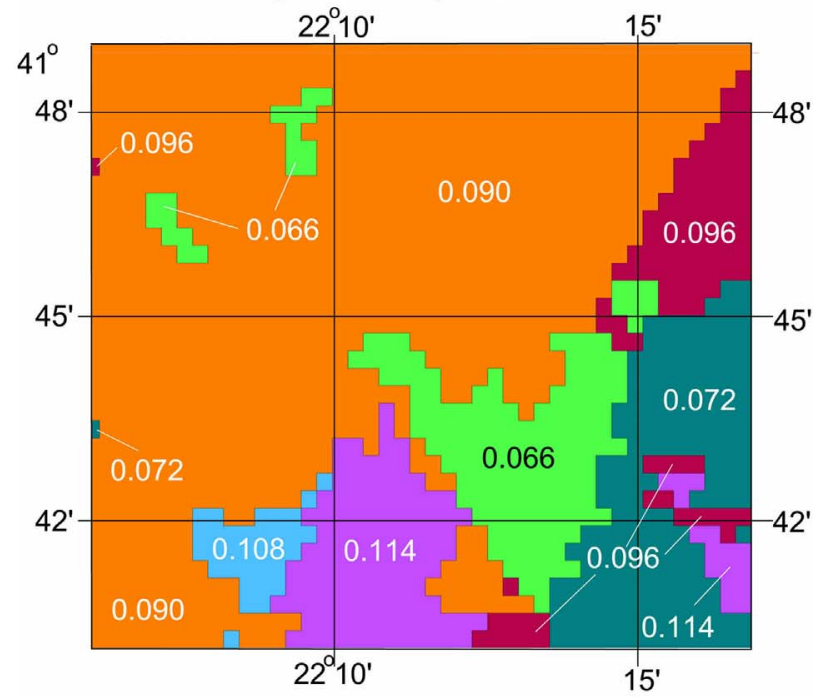

d

Microzonation Map of Štip -with contribution from Vrancea earthquakes Uniform Hazard Spectra - PSA - g, T=1.0 s, $s=0,1,2, S_{L}=1$ Probability of Exceedance $p=10.0 \%$ in 50 Years

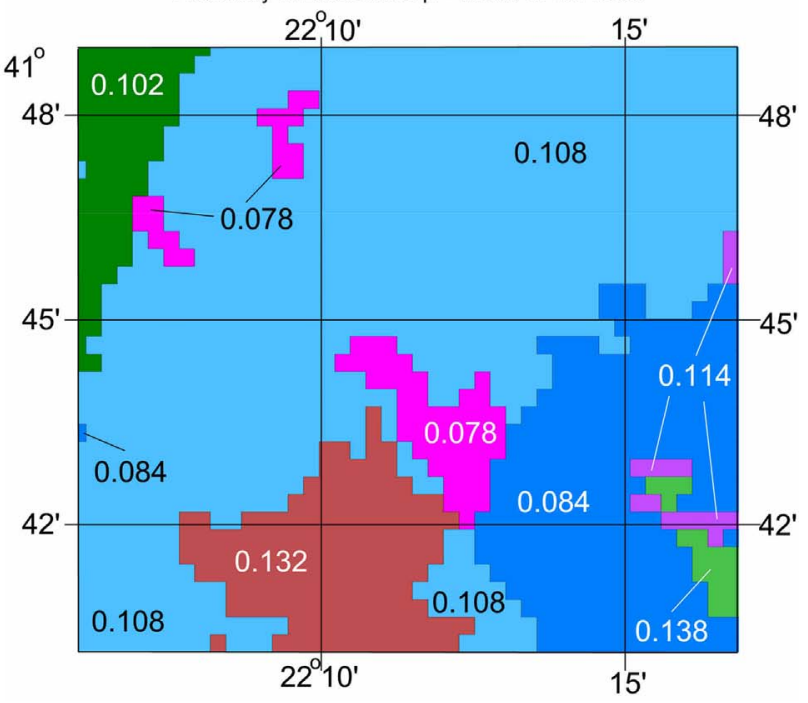

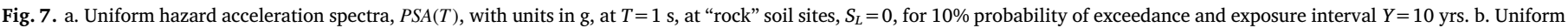

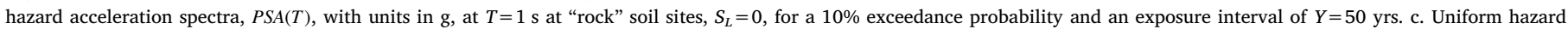

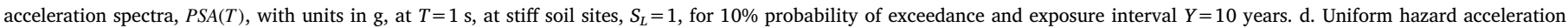
spectra, $P S A(T)$, with units in $\mathrm{g}$, at $T=1 \mathrm{~s}$, at stiff soil sites, $S_{L}=1$, for a $10 \%$ exceedance probability and an exposure interval of $Y=50$ years.

settlement and the Isar and Merite hills in the southwestern part. The thickness of the granite layers is more than five kilometers. Along the Bregalnica River are river terraces, alluviums, and deluviums with relatively small thicknesses. North of the CCR, up to the villages of Karaorman and Čardaklija, the sediments consists of sandstone, marl, and conglomerates, except along the Bregalnica River.

East of the CCR and one-to-one-and-a-half kilometers east from Kemer along the Otinja River, the geology consists of sediments that continue beyond the CCR. Two-to-three kilometers further east, granite prevails, and further east, in the region of the villages of Šašavarlija and Kalapetrovci, we can find mostly Precambrian gneiss with large layer thicknesses and fans of marbles and schists. In the north, smaller regions of limestone and sediments that were formed in the Cretaceous geological period, with a layer thickness of $400-700 \mathrm{~m}$, are present.
South of the village of Lipov Dol, and along the upper course of the Otinja River, there are Pliocene sandstone, gravel, and clay layers, with about $200 \mathrm{~m}$ thickness. Precambrian granite is dominant south of the CCR with large thicknesses, and west, at the confluence of the Kriva Lakavica River into Bregalnica is Pliocene gravel and clay with 200meter thicknesses. West of CCR and north from the Bregalnica River are Eocene sedimentary deposits, with the lower zone comprised of flysch, and the upper zone of the flysch consisting of sandstone, clay, and conglomerates. The thickness of the layers is $400-700 \mathrm{~m}$. West from the village of Suševo, between the Suševo and the Bregalnica River, is Pliocene sandstone, gravel, and clay with thicknesses of $200 \mathrm{~m}$. Northwest of the CCR, along the regional road from Štip to Veles, up to the village of Krivi Dol, are sediments with an upper zone consisting of flysch, limestone, clay, sandstone, and marl, with layer thicknesses of 
a

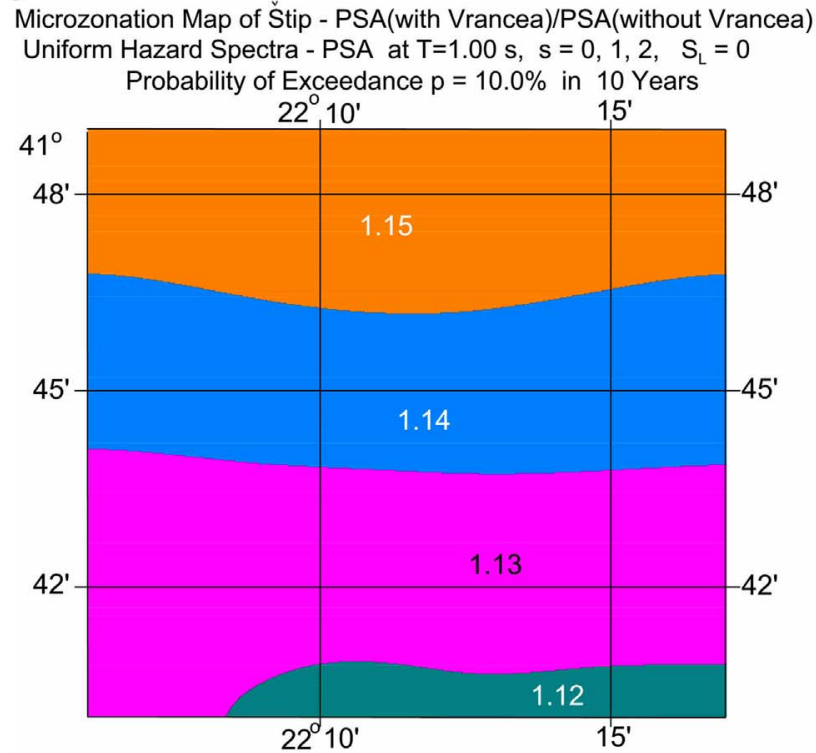

b

Microzonation Map of Stip - PSA(with Vrancea)/PSA(without Vrancea)

Uniform Hazard Spectra - PSA at $T=1.00 \mathrm{~s}, \mathrm{~s}=0,1,2, \mathrm{~S}_{\mathrm{L}}=0$ Probability of Exceedance $p=10.0 \%$ in 50 Years

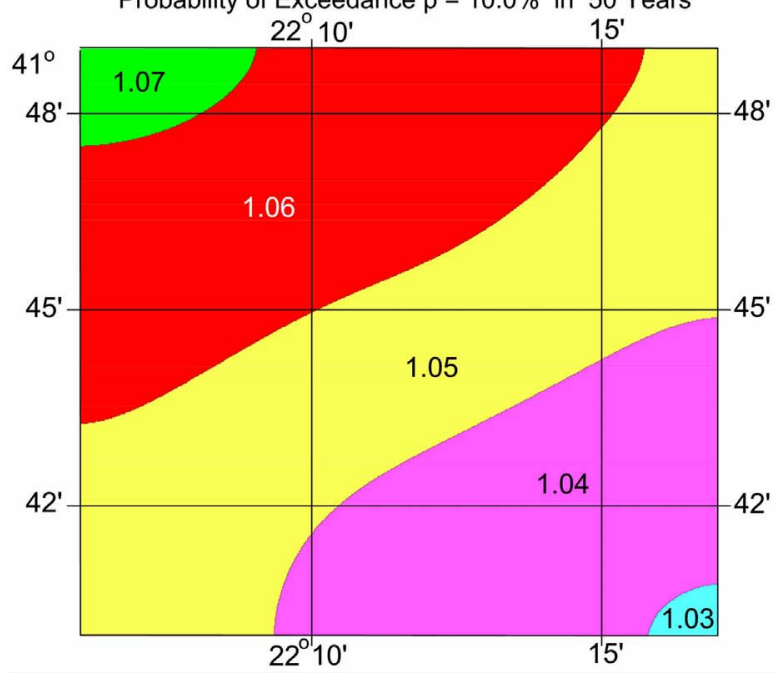

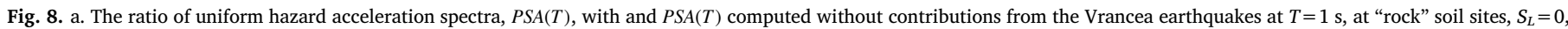

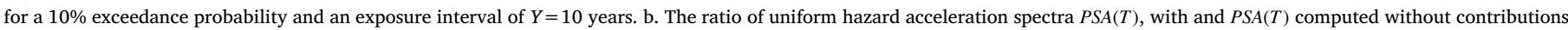
from the Vrancea earthquakes at $T=1 \mathrm{~s}$, at "rock" soil sites, $S_{L}=0$, for a $10 \%$ exceedance probability and an exposure interval of $Y=50$ years.

one-and-a-half kilometers. On the western side of the road from Štip to Veles, is quaternary diluvium that extends to the village of Suševo on the west, the village of Krivi Dol on the north and the Bregalnica River on the south.

Geological site classification for computations of Uniform Hazard Spectra for the area surrounding Štip was based on the interpretation of the geological maps of the Štip region. The geological map that covers most of the area defined by the General Urban Plan of Štip is: "Basic geological map - Štip" [4].

The area that covers most of the "General Urban Plan of Štip" (Fig. 5, left) was divided into cells of $15 \times 15 \mathrm{~s}$ in geographic coordinates between $40^{\prime} \mathrm{N}$ and $41^{\circ} 49^{\prime} \mathrm{N}$; that is, between $22^{\circ} 06^{\prime} \mathrm{E}$ and $22^{\circ} 17^{\prime}$ E. For each of the 1584 analyzed cells, the site geology was described by the predominant lithostratigraphic formations and their depths.

To determine the site condition parameter, $s$, for the city of Štip, we interpreted the description of the site geology by using the classification methodology proposed by Trifunac and Brady [65]. We then classified the site geology for each cell as either basement rock $(s=2)$, alluvial and sedimentary deposits $(s=0)$, or intermediate sites $(s=1)$. The result is shown in the right half of Fig. 5.

\section{Mapping seismic hazard via uniform hazard spectra}

Mapping the amplitudes of $P S A(T)=2 \pi P S V(T) / T$ where $P S A(T)$ is the pseudo absolute acceleration spectrum, $\operatorname{PSV}(T)$ is the pseudo relative velocity spectrum, and $T$ is the oscillator period, for $T=0.04 \mathrm{~s}$ gives an upper bound for peak ground acceleration, since in the limit as $T$ tends to zero, $\operatorname{PSA}(T)$ tends to peak ground acceleration.

Fig. 6a through d show this upper bound for peak ground acceleration for a $10 \%$ exceedance probability, exposure periods of $Y=10$ and 50 years, and for "rock" $\left(S_{L}=0\right)$ and stiff $\left(S_{L}=1\right)$ soil site conditions. Geological site parameters $s$ are included in the hazard calculations. The spatial variations seen in these figures are dominated by the distance to seismic activity east of Štip and by the geological site condition parameters $s=0,1$, and 2 (see Fig. 5, right). For a $10 \%$ exceedance probability and an exposure time of $\mathrm{Y}=50$ years, the peak accelerations in Fig. $6 \mathrm{~b}$ are consistent with our overall regional estimate of about $0.3 \mathrm{~g}$ (shown in Fig. 2). For sites on $S_{L}=1$ (stiff soil) (Fig. 6d), peak accelerations are from 1.3 to 2 times larger.

We note that the amplitudes of peak accelerations shown in
Fig. 6a-d are not sensitive to the occurrence of distant earthquakes in the Vrancea source zone in Romania. Fig. 6a-d further show that peak accelerations are larger on basement rock $(s=2)$ than on intermediate rock sites $(s=1)$ by about $30-45 \%$, for both "rock" soil sites $\left(S_{L}=0\right)$ and for stiff soil sites $\left(S_{L}=1\right)$.

\section{Vrancea earthquake contributions to seismic hazard}

The Vrancea earthquakes occur at large epicentral distances from Štip (Fig. 3). This results in attenuation of high-frequency spectral amplitudes [36,37] so that the UHS for peak accelerations in Štip (Fig. 4), for a typical range of exceedance probabilities, are dominated only by local seismicity. Consequently, for typical hazard mapping of peak accelerations in Štip, the Vrancea earthquakes can be ignored. However, this is different for intermediate- and long-period spectral amplitudes, in which the Vrancea earthquakes $(M>6.5)$ contribute progressively as periods of ground motion become longer.

Fig. 7a-d show the contours of $\operatorname{PSA}(T=1.0 \mathrm{~s})$, with contributions from the Vrancea earthquakes. The Vrancea earthquakes contribute appreciably at $T=1.0 \mathrm{~s}$, which progressively increases in Macedonia as one moves northeast [32]. The contribution of Vrancea sources is also larger where the local seismicity is relatively low (see Appendix A and Fig. 4).

A detailed comparison of Fig. 7a-d with Fig. 6a-d shows that the spatial distribution of short- and long-period amplitudes is different. This is caused by variable shapes of UHS and by the contribution to spectral amplitudes from the Vrancea sources with strong motion waves arriving from the northeast. Fig. $8 \mathrm{a}$ and $\mathrm{b}$ show this in terms of the ratios of spectral amplitudes computed relative to the spectral amplitudes without contribution from the Vrancea sources. While the contribution of the Vrancea earthquakes does increase with a decreasing epicentral distance, the ratios in these figures are still dominated by the northwest and south and southeast sources from Štip (see Fig. A1).

The relative increase of spectral amplitudes due to the contributions from Vrancea earthquakes, shown in Fig. 8a and b, is the same for all comparisons among the same geological site conditions ( $s=0,1$ and 2) and for the oscillator period shown $(T=1.00 \mathrm{~s})$. However, the amplitudes of $P S A(T)=(2 \pi / T) P S V$ for UHS at $T=1.00 \mathrm{~s}$ at sites on intermediate rocks $(s=1)$ will be larger than at the basement rock sites $(s=2)$. In this paper, we show many results for the sites on geological 


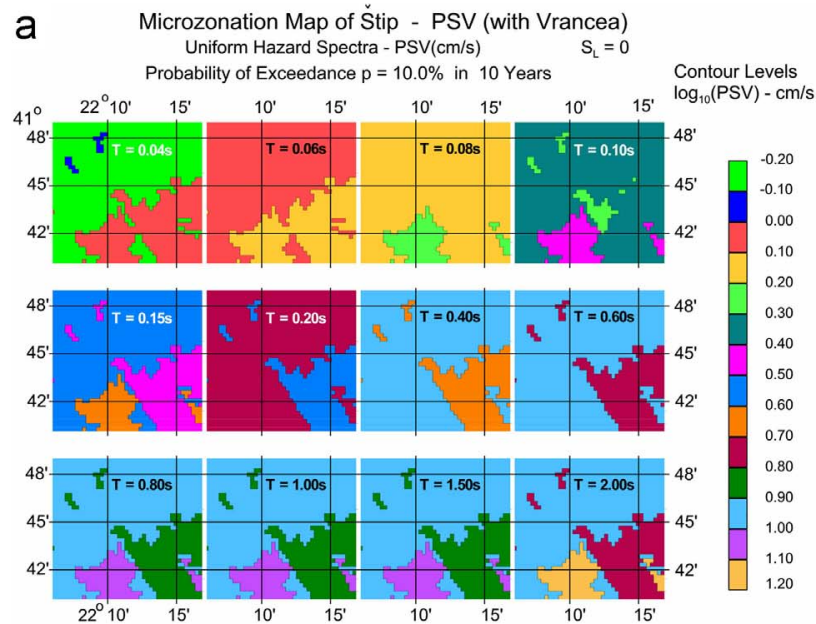

C Microzonation Map of Štip - PSV (with Vrancea)

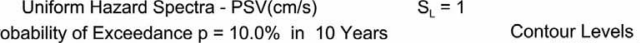

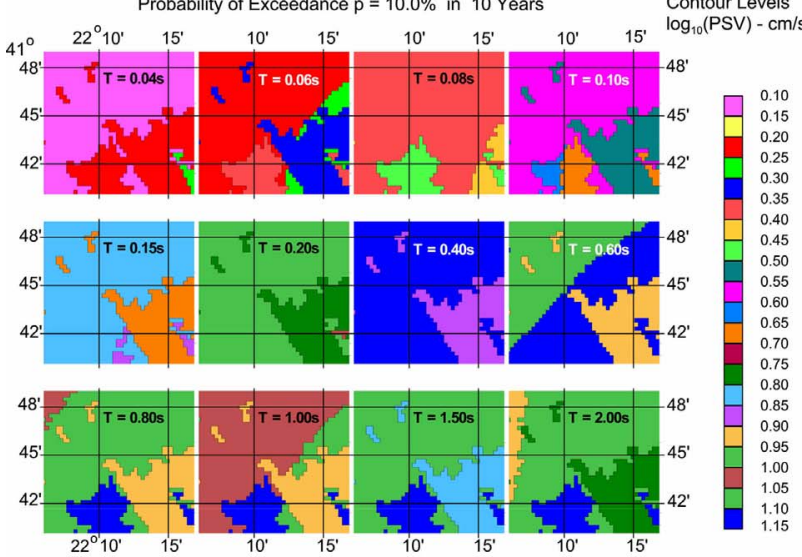

b

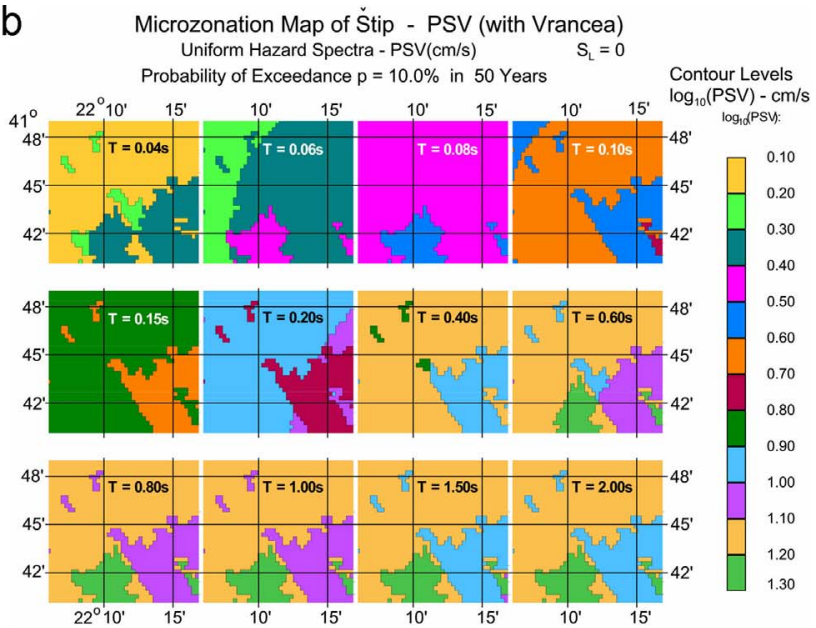

d Microzonation Map of Šlip - PSV (with Vrancea)

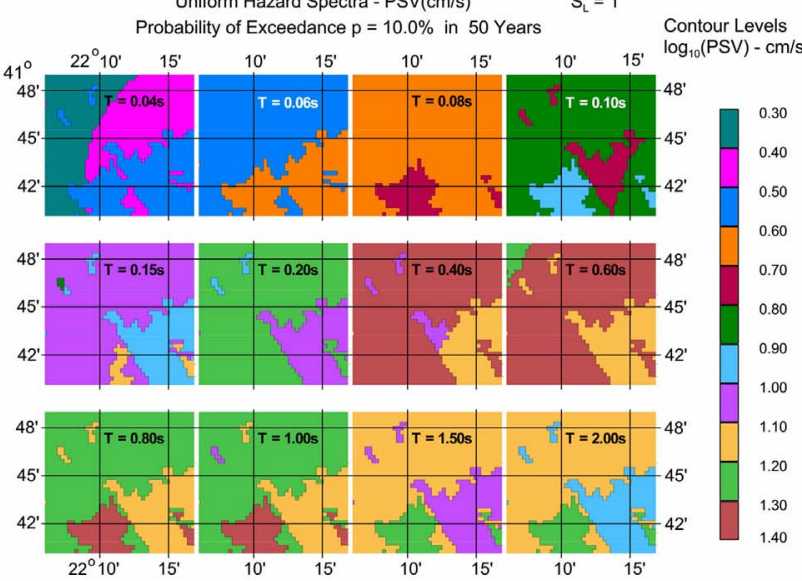

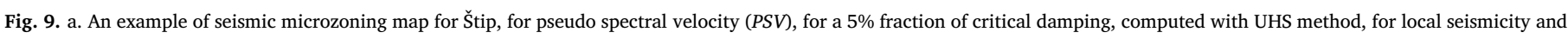

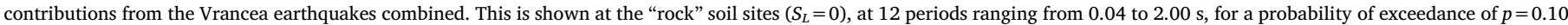

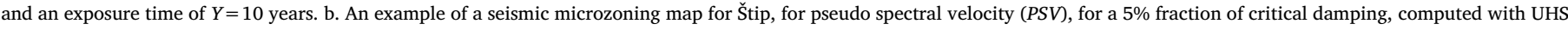

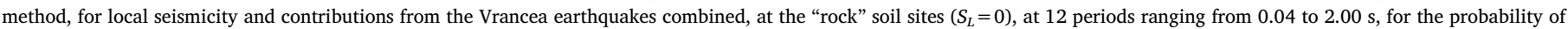

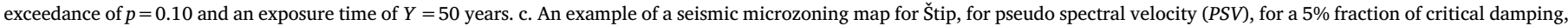

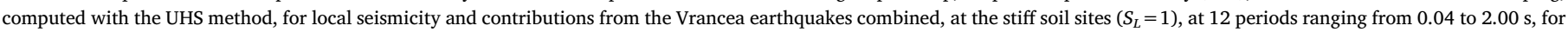

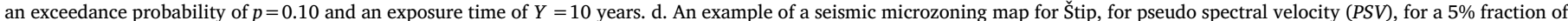

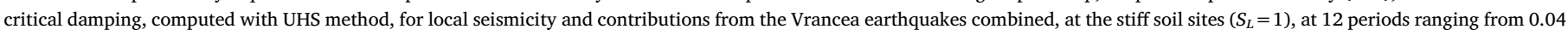
to $2.00 \mathrm{~s}$, for an exceedance probability $p=0.10$ and an exposure time of $Y=50$ years.

basement rock $(s=2)$ to facilitate qualitative comparisons with previously published results by others, which are all shown only for type A sites.

\section{Practical determination of UHS}

UHS at a site can be calculated for each site-specific condition, but these calculations are time consuming and require detailed knowledge to select the required scaling parameters. A simple alternative for engineering applications, which we introduced in the mid-1980s, is to prepare maps of UHS for given response periods, site conditions, probabilities of exceedance, and exposure time, and then to read the spectral amplitudes from the contours in the maps. Our report entitled, "Microzonation of a Metropolitan Area," describes this procedure and presents examples of how it can be carried out [27]. Fig. 9a-d show examples of such maps for $\log _{10} P S V(T)$ amplitudes, at 12 periods ranging from $0.04 \mathrm{~s}$ to $2.00 \mathrm{~s}$, for a $5 \%$ damping, horizontal motions, at "rock" and stiff soil sites ( $S_{L}=0$ and 1 ), for a 10\% probability of being exceeded and exposure periods of $Y=10$ and 50 years. By reading the spectral amplitudes at the given location, the UHS of PSV can be constructed by interpolating the values read from 12 periods. Examples of such an outcome are illustrated in Figs. 10a-11b, at two sites with different geological site parameters (Stadion Suitlak, with $s=2$ and $S_{L}=0$ and Stip City Center, with $s=1$ and $S_{L}=1$ ).

A perusal of Fig. 9a-d shows that, in the contoured areas, there are many jumps from one level to an adjacent one that do not have a gradual transition (we will illustrate the reasons for this at $T=0.2 \mathrm{~s}$ ). This can be understood by looking at the spectral scaling equation in Lee [21] that describes $P S V(T)$ versus magnitude, and geological and soil site conditions:

$$
\begin{aligned}
\log _{10}(P S V(T))= & M+\operatorname{Att}(\Delta, M, T)+b_{1}(T) M \\
& +b_{2}^{1}(T) S^{(1)}+b_{2}^{2}(T) S^{(2)}+\ldots .
\end{aligned}
$$

where $P S V(T)$ takes on discrete values for $s=1\left(S^{(1)}=1\right)$ and $s=2\left(S^{(2)}=1\right)$, and for damping 0.05. From Table IIIc in Lee [21] at $T=0.2 \mathrm{~s}$, for example, $b_{2}^{1}=0.007$ and $b_{2}^{2}=-0.220$, which is a considerable change. Next, looking at the figures where $s=2$ changes to $\mathrm{s}=1, P S V(T)$ levels jump 2 steps. We do not smooth the contour levers, because every point is considered as a discrete estimate. Hence, the transitions across the borders of two different $s$ values are not smooth, but sudden. 
a

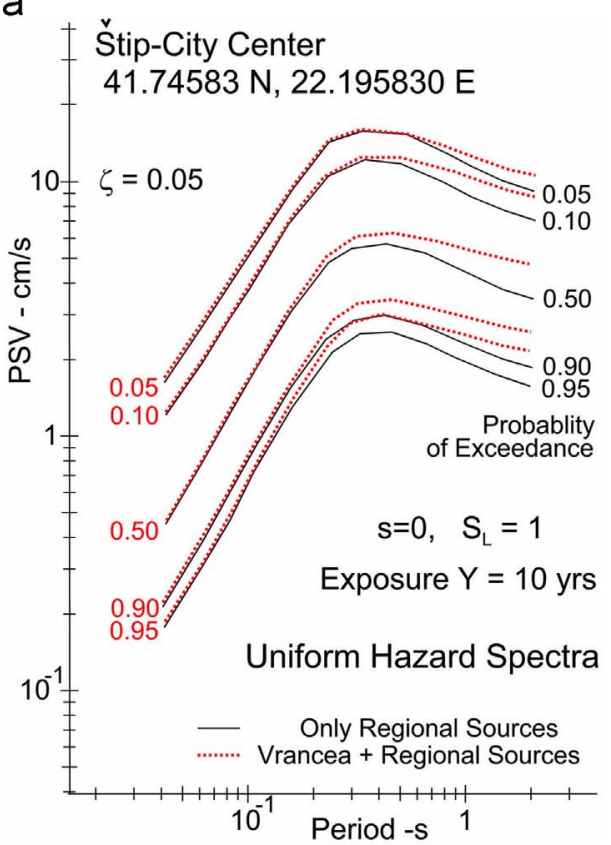

b

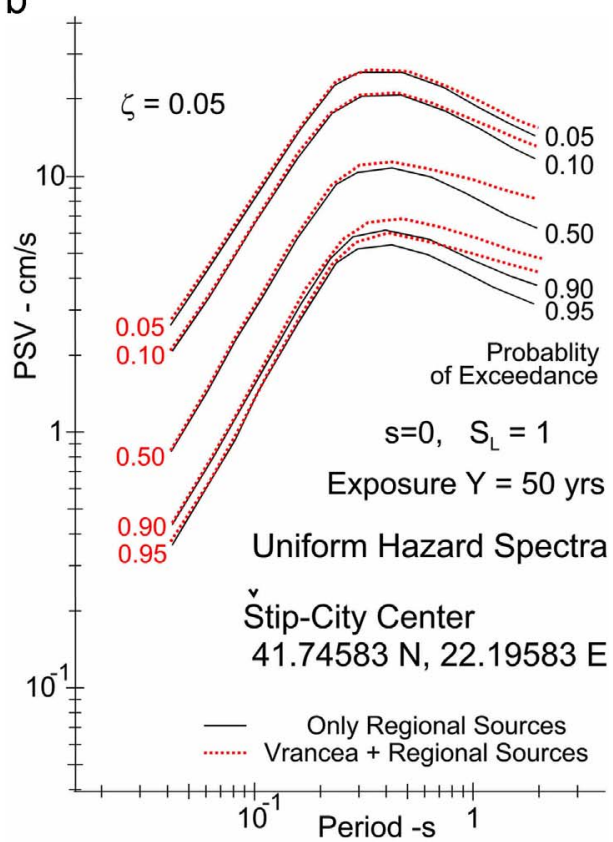

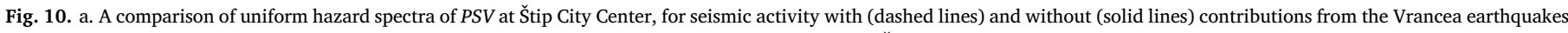

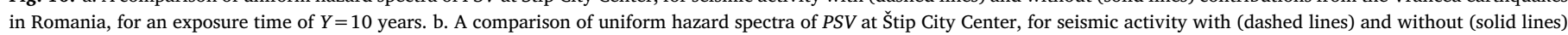
contributions from the Vrancea earthquakes in Romania, for exposure time of $Y=50$ years.

a

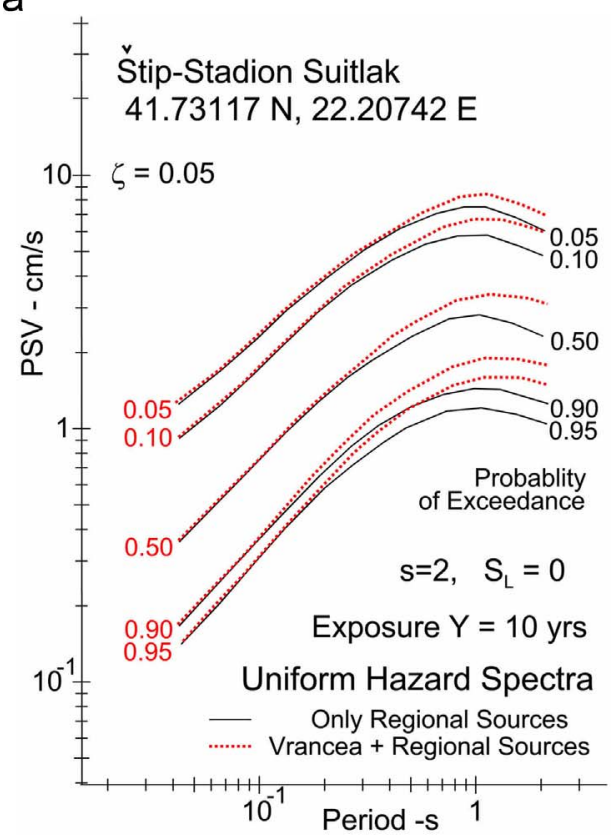

b

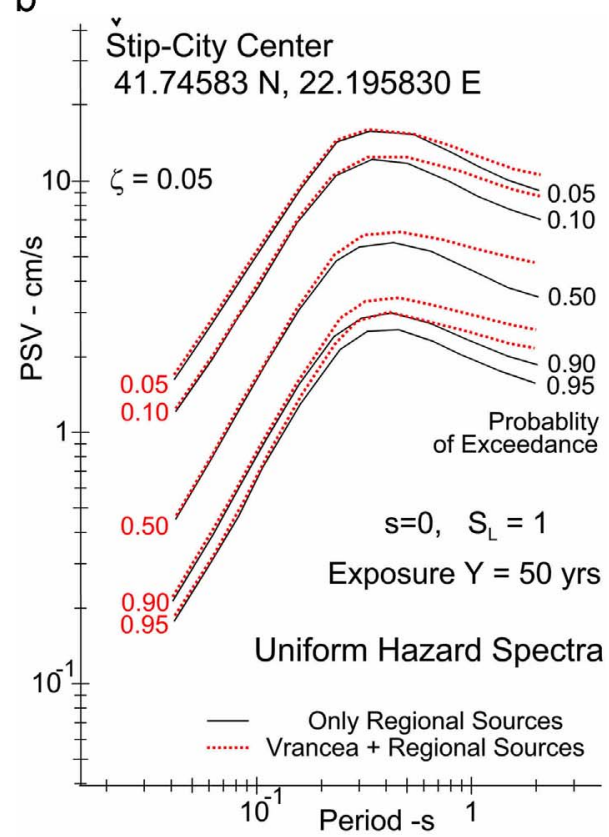

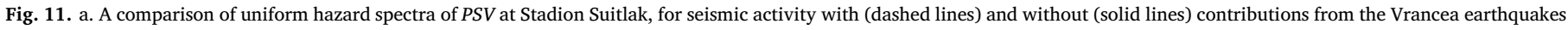

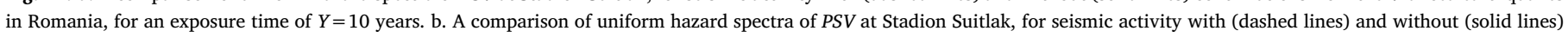
contributions from the Vrancea earthquakes in Romania, for an exposure time of $Y=50$ years.

Figs. 10a-11b all show monotonically increasing contributions from the Vrancea sources as the oscillator periods become longer. At $T=2 \mathrm{~s}$ and average spectral amplitudes, these increases range from $31 \%$ to $37 \%$ for the Štip City Center, and from $38 \%$ to $40 \%$ for Stadion Suitlak, for $p=0.5$ and $Y=10$ and 50 years, for example. Overall, long-period spectral amplitudes tend to be larger on $s=1$ and $S_{L}=1$ (Štip - City Center, Fig. 10a,b) than on $s=2$ and $S_{L}=0$ (Stadion Suitlak - Fig. 11a,b) provided the sites are at comparable distances from the large Vrancea sources, as shown in these examples.

\section{Conclusions}

We have shown that the regional variations of UHS amplitudes over an area of a large city can be considerable. In the examples shown for Štip, three sources of these variations include: (1) the geological and soil site conditions, (2) the local seismicity that is mainly east of Štip, and (3) the contributions from the large Vrancea earthquakes, at a distance of about $600 \mathrm{~km}$ northeast, in Romania. The relative contributions from these sources will differ between cities, depending on the degree to which geologic and soil site conditions vary, as well as on the 
relative strength of local versus distant earthquakes.

Almost everywhere in Macedonia peak accelerations will be dominated by the local seismic activity, and contributions from the Vrancea earthquakes can be neglected. However, in many areas of the country, the intermediate- and long-period spectral amplitudes are affected by contributions from large Vrancea earthquakes. These contributions are weakest in southwestern and southeastern Macedonia and strongest in the northcentral parts of the country [32].

Throughout this paper, we have used empirical scaling equations in all calculations that were developed from strong motion data recorded in the former Yugoslavia [28,29,37]. As this data had only a few recordings on deep soil sites $\left(S_{L}=2,[59,61]\right)$, our empirical scaling equations for PSV amplitudes do not include the scaling in terms of $S_{L}=2$. Therefore examples including $S_{L}=2$ are not included in this paper. For future engineering designs, and to approximate the expected amplitudes, at $S_{L}=2$ sites, additional analyses will be required to modify the UHS presented in this paper. This can be based on several other scaling equations that include $S_{L}=2$ scaling factors in California and elsewhere [24].

Finally, it is noted that all results presented in this paper are only of a preliminary nature. Our scaling models for strong ground motion in the former Yugoslavia are more than 20 years old and based on strong motion data that was recorded up to the early 1980s [16,66,67]. Although our model for the scaling of PSV spectra in Serbia for earthquakes in the Vrancea source zone was published recently (and which we are also using in this paper for Štip), it only includes the data for large Vrancea earthquakes.

More detailed and comprehensive analyses of this kind will be possible when new and abundant recordings of local and Vrancea earthquakes become available. It is hoped that the current analysis will help motivate and guide observational programs that will contribute such needed data. Last but not least, it is hoped that our profession will abandon outdated and ill-founded methods of scaling strong motion amplitudes, as in using the site classification in terms of $V_{30}$ or A, B, C, and $\mathrm{D}$, for example, and will finally realize that scaling the design spectra by peak acceleration and fixed shape spectra is not conservative.

\section{Acknowledgments}

Research work of the third author was supported in part by the Serbian Ministry of Education, Science, and Technology Development Grant No. 36043.

\section{Appendix A. Seismic activity and seismicity model}

To illustrate computations for the strong motion earthquake hazard, we briefly summarize the data on seismic activity surrounding investigated locations and procedures for deriving the relevant seismicity model. The earthquake activity in the region is assumed to be well represented by a catalog compiled by merging records listed in the following catalogs:

- the BSHAP2 catalog (510 BCE-2012) compiled during the BSHAP2 NATO-funded project by seismologists from Albania, Croatia, Macedonia, Montenegro, Serbia, and Turkey [39];

- the ISC-catalog (2013-2014) (http://www.isc.ac.uk).

If not reported as such, all magnitudes were converted to moment magnitudes $\left(M_{w}\right)$ using regionally adjusted regressions between $M_{w}$ on one side and $M_{S}, M_{L}$, or $m_{b}$ on the other [39]. The catalog was declustered using time-space windows the size of which depend on the mainshock's magnitude as described, for example, in Herak et al. [12], thus removing dependent events (foreshocks and aftershocks). In estimating recurrence parameters, only mainshocks with magnitudes exceeding 3.4 were considered. Fig. A1 shows the geographical distribution of earthquake epicenters.

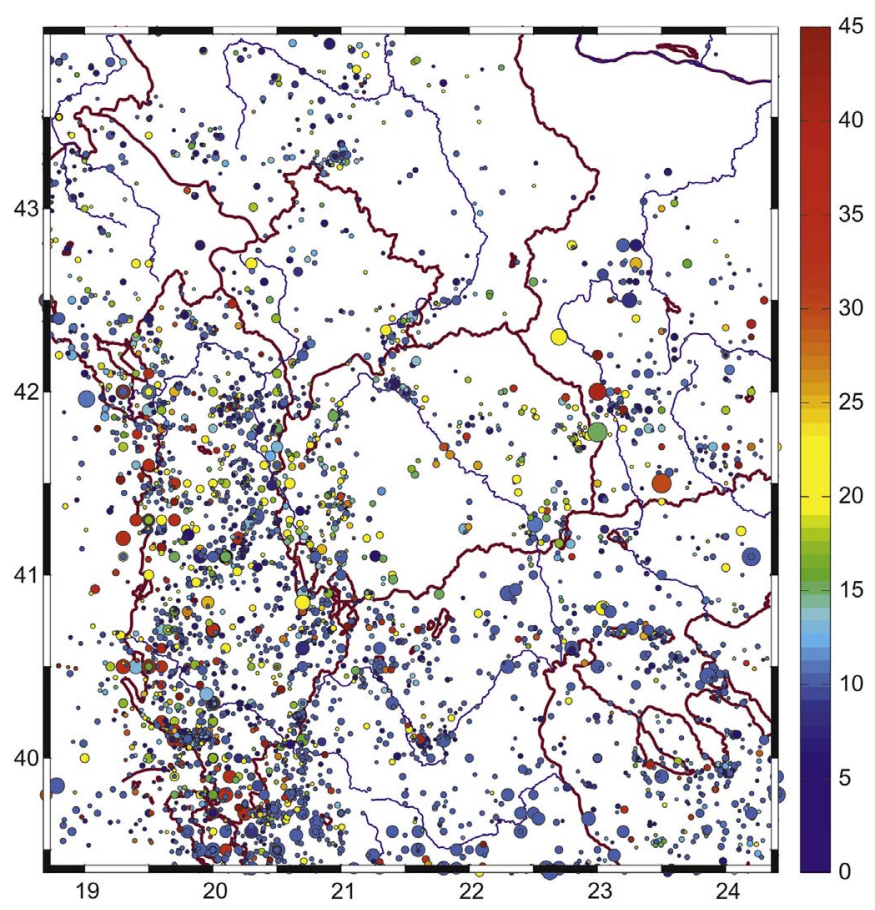

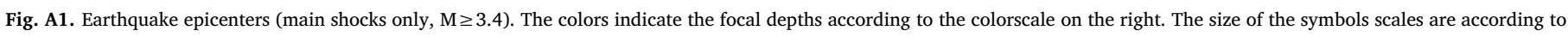
magnitude. 
Seismic activity is described by the earthquake occurrence rate in terms of moment magnitude $\left(M=M_{w}\right)$, assuming the validity of the truncated Gutenberg-Richter recurrence relation:

$N(M)= \begin{cases}10^{a-b M} & M_{\min } \leq M \leq M_{\max } \\ 0 & \text { otherwise }\end{cases}$

where $N(M)$ is the number of events with magnitudes greater than or equal to $M$, and $M_{\min } \leq M \leq M_{\max }$ is the allowable range of magnitudes. $M_{\min }$ varies in space and time according to the completeness of the contributing catalog(s), and the distribution of $M_{\max }$ (Fig. A2) is assumed by taking into account the magnitudes and intensities of the largest historical earthquakes and the lengths of the known major fault segments. The spatial and temporal completeness of the catalog (see Fig. A3 for examples) was estimated as proposed by Herak et al. [12] (for details, see also [13]).

The seismicity of the region was modeled using a variant of the distributed smoothed seismicity approach [e.g., Frankel [7] and Frankel et al. [8]; see also Lapajne et al. [20] who applied it to model the seismicity of Slovenia]. This method was also used to compile the earthquake hazard maps for Croatia [11] that are adopted as base maps in the National Annex to EC8 [14]. For computations, the region is divided into a mosaic of rectangular cells $\left(0.1^{\circ} \times 0.1^{\circ}\right.$, or approximately $\left.11.1 \times 11.1=123 \mathrm{~km}^{2}\right)$. For each cell, parameters $a$ and $b$ in Eq. (A.1), along with their uncertainties, are calculated, taking the magnitude completeness thresholds into account. Parameter $b$ is estimated using the maximum-likelihood algorithm of Weichert [73], which considers only earthquakes above their respective completeness thresholds within the smallest circle centered in each of the cells that holds at least 40 such events. The resulting spatial distribution of the $b$-value is shown in Fig. A2. $a$ is assessed by counting the number of
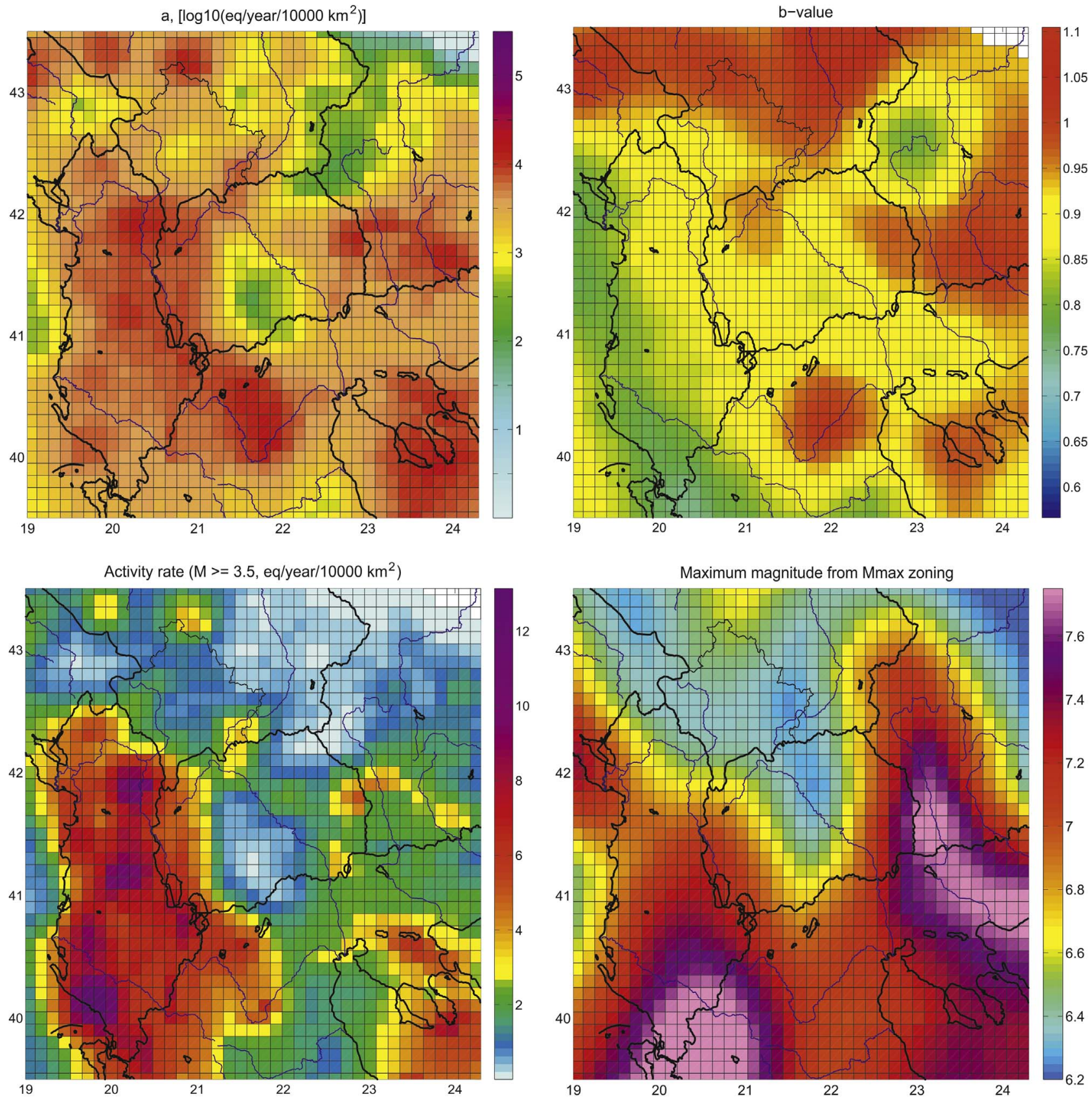

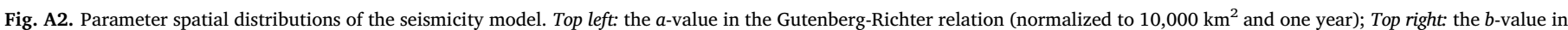
the Gutenberg-Richter relation; Bottom left: the activity rate for $\mathrm{M} \geq 3.5$ (number of events normalized to one year and 10,000 km ${ }^{2}$ ); Bottom right: maximum magnitude, Mmax. 

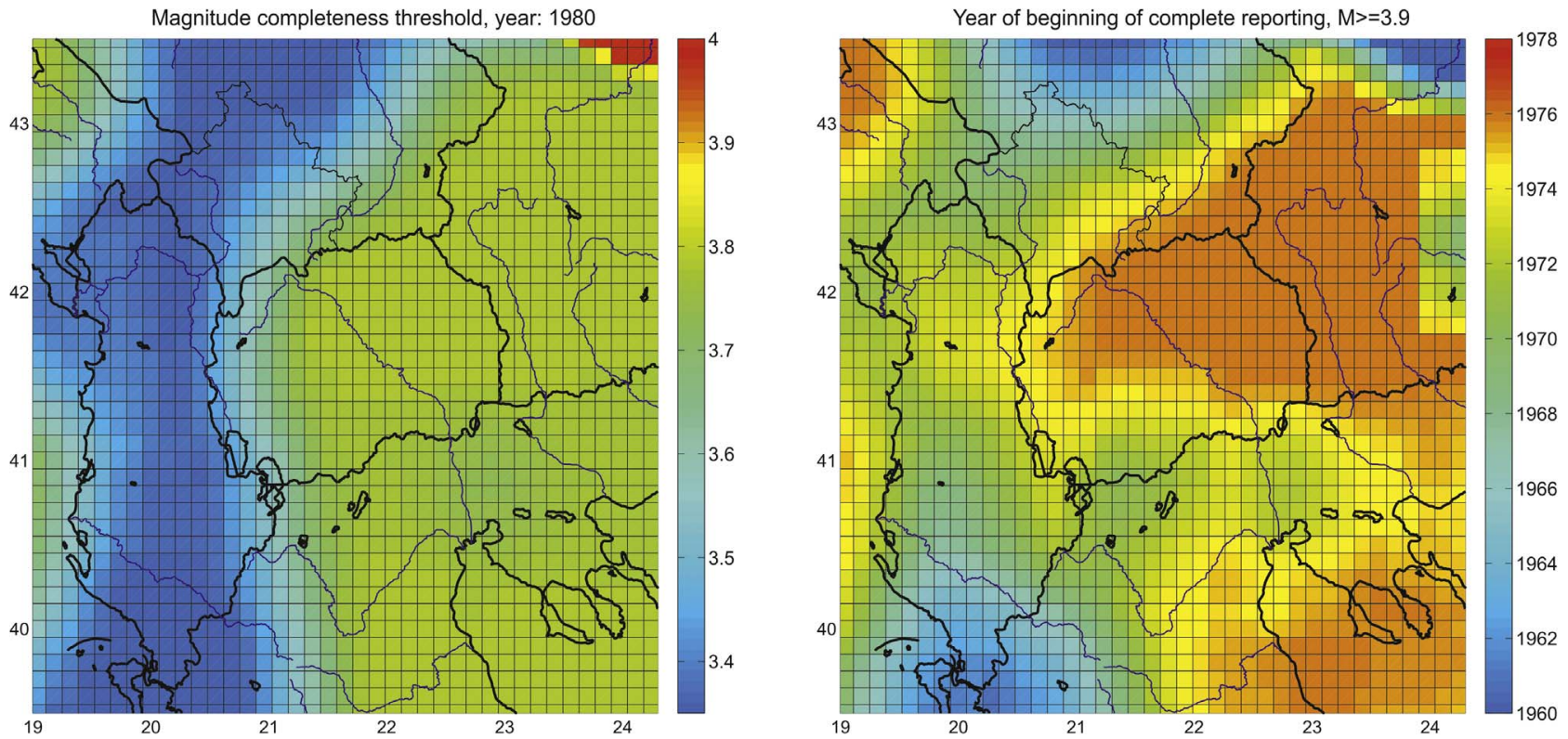

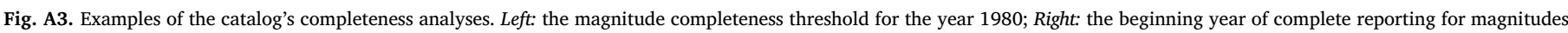
$\geq 3.9$.

events $\mathrm{N}_{1}=\mathrm{N}(M \geq 3.5), \mathrm{N}_{2}=\mathrm{N}(M \geq 3.8), \mathrm{N}_{3}=\mathrm{N}(M \geq 4.2)$ within the circle that occurred after the corresponding onset of complete reporting. For each $\mathrm{N}_{\mathrm{i}}, \mathrm{N}_{0 \mathrm{i}}(b)=10^{a}$ is estimated using Eq. (A.1), and representative $a$ is obtained by taking the logarithm of the average. The seismicity rates thus obtained are normalized to one year and to an area of $10,000 \mathrm{~km}^{2}$. After $a$-values were assigned to each of the grid-cells, the resulting spatial distribution is smoothed using a bivariate, normal-elliptical smoothing kernel (for an example, see e.g., [20], with the major axis directed along the predominant strike of faults within the corresponding source zone whenever it is known. We extracted such information here from the database of seismogenic faults, which is one of the products of the SHARE-project [5], http://diss.rm.ingv.it/share-edsf/), and also lists the corresponding predominant style of faulting (normal, reverse, strike-slip). If the predominant strike was unknown, circular Gaussian smoothing was applied. The widths of Gaussian distribution (standard deviations) along the major and minor axes are scaled to the expected maximum fault length and to the width of the surface projection of the fault plane, respectively, estimated for the corresponding $M_{\max }$ in the cell by relations of Wells and Coppersmith [74]. In this way, the seismogenic potential estimated on the basis of past earthquakes that occurred in the neighborhood of each of the grid-cells, is distributed along the known faults systems. The seismicity model is then defined for each of the cells by the following parameters:

- geographical coordinates of the cell center,

$-a$-value, and its standard deviation,

- $b$-value, and its standard deviation,

- maximum moment magnitude, $M_{\max }$

- average focal depth $(\mathrm{km})$, and its standard deviation,

- predominant strike of the seismogenic faults $\left({ }^{\circ}\right)$, and its standard deviation,

- predominant style of faulting (unknown, normal, reverse, strike-slip).

Our seismicity model is mostly based on the past seismicity record. The model does not explicitly consider fault-sources, as we feel that necessary data on positions of seismogenic faults, their segmentation, geometry, Quaternary activity rates, and so forth, are still far from reliably known and complete. Nevertheless, as noted above, the model includes some of the fault-specific data (predominant strike, the style of faulting, lengths of some known segments) when such data were available.

\section{Appendix B. Seismicity of the Vrancea source zone}

The Vrancea earthquakes in Romania occur near a sharp bend of the southeastern Carpathians [15]. The seismicity is concentrated in a highvelocity focal volume in the depth range from about $60-200 \mathrm{~km}$ [48]. At shallower depths (0-60 km), earthquakes occur sporadically and are not large, with magnitudes typically below 5.5. Source properties of large Vrancea earthquakes and the geology of the surrounding areas generally lead to elongation of the intensity contours toward the southwest and Serbia and Macedonia. This is illustrated in Fig. 3 by the intensity contours of the 1977 earthquake [19]. The cities in Macedonia were at considerable epicentral distances from this Vrancea earthquake, from 550 to $730 \mathrm{~km}$ (Stip 598; Skopje - 619; Ohrid - 726 km). In regards to the earthquake of March 4, 1977, Stip was in zone V (MSK scale), while Skopje and Ohrid were in zone IV.

Historical data on earthquake occurrences in Vrancea have been compiled by Radu [45] and Purcaru [43]. The corresponding Gittenberg-Richter trend $\log _{10} N=a-b M$, which describes the number of earthquakes $N$ per year greater or equal to a magnitude $M$, has been studied by many authors. Here we mention Radulian et al. [44] who give $a=4.77 \pm 0.24$ and $b=0.89 \pm 0.04$; Wenzel et al. [72] and Oncescu et al. [41] who give $a=4.10$ and $b=0.78$; and Paskaleva [42] who gave $a=4.21$ and $b=0.80$. The associated estimates of the largest possible magnitude for Vrancea events range from 7.8 to 8.1. In Fig. B1 we also reproduce the observed values of $N$ versus $M$ for the period between 1980 and 1997 (redrawn from [41]. For the calculations in this paper we assumed $a=4.10 \pm 0.24, b=0.78 \pm 0.04$ and that $M_{\max }$ is uniformly distributed between 7.9 and 8.1. 


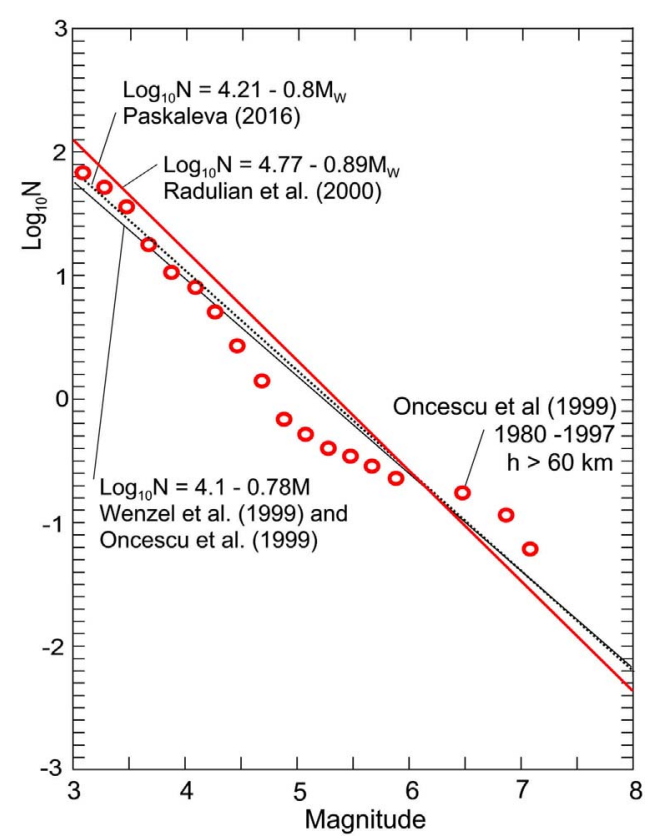

Fig. B1. The number of earthquakes greater or equal to $M$, per year, in the Vrancea source zone in Romania.

\section{References $^{2,3}$}

[1] Akademia Nauk, SSSR. Seismicheskoe Reionirovanie Teritorii SSSR. Moskva: Izdatelstvo Nauka; 1980.

[2] Anderson JG, Trifunac MD. Uniform risk functionals for characterization of strong earthquake ground motion. Bull, Seism Soc Am 1978;68:205-18.

[3] Anderson JG, Trifunac MD. Application of Seismic Risk Procedures to Problems in Microzonation, In: Proceedings of the Second International Conference on Microzonation, San Francisco, 559-569; 1978b.

[4] Basic geological map - Štip. Basic geological map - Štip, K34-K81, Geological Institute, Skopje, editorial and publication of the Federal Geological Institute of Belgrade; 1976.

[5] Basili R, Kastelic V, Demircioglu MB, Garcia Moreno D, Nemser ES, Petricca P, Sboras SP, Besana-Ostman GM, Cabral J, Camelbeeck T, Caputo R, Danciu L, Domac H, Fonseca J, García-Mayordomo J, Giardini D, Glavatovic B, Gulen L, Ince Y, Pavlides S, Sesetyan K, Tarabusi G, Tiberti MM, Utkucu M, Valensise G, Vanneste K, Vilanova S, Wössner J. The European Database of Seismogenic Faults (EDSF) compiled in the framework of the Project Share.〈http://diss.rm.ingv.it/share-edsf/ >, doi: 10.6092/INGV.IT-SHARE-EDSF; 2013.

[6] Eurocode 8. Design provisions of structures for earthquake resistance - Part 1: General rules, seismic actions and rules for buildings (EN1998-1)/CEN Techn. Comm. 250 - SC8, CEN, Brussels; 2005.

[7] Frankel A. Mapping seismic hazard in the central and eastern United States. Seism Res Lett 1995;66:8-21.

[8] Frankel A, Mueller C, Barnhard T, Leyendecker E, Wesson R, Harmsen S, Klein F, Perkins D, Dickamn N, Hanson S, Hopper M. USGS national seismic hazard maps. Earthq Spectra 2000;16:1-20.

[9] Gubin IE. On some questions of seismic regionalization. Akad Nauk SSSR, Tr Geofiz Inst 1954;25(152):36-73.

[10] Gupta ID, Trifunac MD. Order statistics of peaks in earthquake response. J Eng Mech, ASCE, EMD 1988;114(10):1605-27.

[11] Herak M. Republika Hrvatska, Karta potresnih područja, 〈http://seizkarta.gfz.hr〉 et al., 2011.

[12] Herak D, Herak M, Tomljenović B. Seismicity and focal mechanisms in NorthWestern Croatia. Tectonophysics 2009;465:212-20. http://dx.doi.org/10.1016/j. tect.2008.12.005.

[13] Herak M, Herak D. Analyses of seismicity as input for earthquake hazard studies in Bosnia and Herzegovina, Chapter 1, in Selected Topics in Earthquake Engineering from earthquake source to seismic design and hazard mitigation, published by ZIBL, Banja Luka, Republic of Srpska, Oct. 2009, 1-24; 2009.

[14] Hrvatski zavod za norme. HRN EN 1998-1:2011/NA: 2011, Eurokod 8: Projektiranje potresne otpornosti konstrukcija - 1. dio: Opća pravila, potresna djelovanja i pravila za zgrade - Nacionalni dodatak (Eurocode 8: Design of structures for earthquake resistance - Part 1: General rules, seismic actions and rules for buildings - National Annex); 2011.

\footnotetext{
${ }^{2}$ Can be downloaded from http://www.usc.edu/dept/civil_eng/Earthquake_eng/.

${ }^{3}$ Can be downloaded from http://home.iitk.ac.in/ vinaykg/iset.html.
}

[15] Ismail-Zadeh AT, Panza GF, Naimark BM. Stress in the descending relic slab beneath the vrancea region, Romania. Pure Appl Geophys 2000;157:111-30.

[16] Jordanovski LR, Lee VW, Manić MI, Olumčeva T, Sinadinovski C, Todorovska MI, Trifunac MD. " Strong earthquake ground motion data in EQINFOS: yugoslavia, Part I, Civil Eng. Report CE 87-05. Los Angeles, CA: Univ. of Southern California; 1987.

[17] Kanai K. Engineering Seismology. Tokyo, Japan: Univ. of Tokyo Press; 1983.

[18] Karnik V. Microzoning Programme within the UNDP-UNESCO Survey of Seismicity of Balkan Region, Proceedings Microzonation Conference, Seattle, Washington, I, 213-215, 1972.

[19] Kronrod T, Radulian M, Panza G, Popa M, Paskaleva I, Radovanovich S, Gribovszki K, Sandu I, Pekevski L. Integrated transnational macroseismic data set for the strongest earthquakes of Vrancea (Romania). Tectonophysics 2013;590:1-23.

[20] Lapajne J, Šket Motnikar B, Zupančič P. Probabilistic seismic hazard assessment methodology for distributed seismicity. Bull Seism Soc Am 2003;93:2502-15.

[21] Lee VW. Pseudo relative velocity spectra in former Yugoslavia. Eur J Earthq Eng 1995;VII(1):12-22.

[22] Lee VW. Discussion: prediction of horizontal response spectra in Europe. Int J Earthq Eng Struct Dyn 1997;26(2):289-93.

[23] Lee VW. ${ }^{1}$ Empirical scaling of strong earthquake ground motion: part I: attenuation and scaling of response spectra. ISET J Earthq Technol 2002;39(4):219-54.

[24] Lee VW. ${ }^{1}$ Empirical scaling and regression methods for earthquake strong-motion spectra-A review. ISET J 2007;44(1):39-69.

[25] Lee VW, Manić MI. Empirical scaling and regression methods for strong earthquake ground motions in Yugoslavia-A review. Izgradnja 2009;2009(5-6):234-57.

[26] Lee VW, Trifunac MD. "Uniform Risk Spectra of Strong Earthquake Ground Motion. Los Angeles, California: Department of Civil Engineering, Report CE85-05, University of Southern Calif.; 1985.

[27] Lee VW, Trifunac MD. "Microzonation of a Metropolitan Area. Los Angeles, California: Department of Civil Engineering, Report CE 87-02, University of Southern California; 1987.

[28] Lee VW, Trifunac MD. Frequency dependent attenuation of strong earthquake ground motion in Yugoslavia. Eur Earthq Eng 1992;VI(1):3-13.

[29] Lee VW, Trifunac MD. Empirical scaling of fourier amplitude spectra in former Yugoslavia. Eur Earthq Eng 1993;VII(2):47-61.

[30] Lee VW, Trifunac MD. Should average shear wave velocity in the top $30 \mathrm{~m}$ of soil be the only local site parameter used to describe seismic amplification? Soil Dyn Earthq Eng 2010;30(11):1250-8.

[31] Lee VW, Trifunac MD. Seismic hazard maps in Serbia, submitted for publication; 2017a.

[32] Lee VW, Trifunac MD. Seismic hazard maps in Macedonia, submitted for publication; 2017b.

[33] Lee VW, Herak M, Herak D, Trifunac MD. Uniform hazard spectra in Northwestern Bosna and Hercegovina. Izgradnja 2010;64(5-6):282-304.

[34] Lee VW, Trifunac MD, Herak M, Herak D. Uniform hazard earthquake acceleration spectra in Kraljevo - contributions from local seismicity. Izgradnja 2011;65(5-6):227-35.

[35] Lee VW, Trifunac MD, Herak M, Herak D. Minimum radius of seismic activity for earthquake hazard analyses. Izgradnja 2011;65(5-6):219-26.

[36] Lee VW, Trifunac MD, Bulajić B, Manić M. A preliminary empirical model for frequency-dependent attenuation of Fourier amplitude spectra in Serbia from the Vrancea earthquakes. Soil Dyn Earthq Eng 2016;83:167-79. 
[37] Lee VW, Trifunac MD, Bulajić B, Manić M. Preliminary empirical scaling of pseudorelative velocity spectra in serbia from the vrancea earthquakes. Soil Dyn Earthq Eng 2016;86:41-54.

[38] Liao ZP. Seismic Microzonation in China, Instt. of Engineering Mechanics, State Seismological Bureau, Research Report, 1-37; 1985.

[39] Markušić S, Gülerce Z, Kuka N, Duni L, Ivančić I, Radovanović S, Glavatović B, Milutinović Z, Akkar S, Kovačević S, Mihaljević J iR Šalić. An updated and unified earthquake catalogue for the western balkan region. Bull Earthq Eng 2016;14(2):321-43.

[40] Medvedev SV. Inzenernaya Seizmologiya, Akademia Nauk SSSR. Inst. Fiziki Zemli, Moskva; 1962.

[41] Oncescu MC, Marza VI, Rizescu M, Popa M. The Romanian earthquake catalogue between 1984-1997. In: Wenzel F, Lungu D, Novak O, editors. Vrancea Earthquakes: Tectonics, Hazard and Risk Mitigation. Dordrecht: Kluwer; 1999. p. 43-7.

[42] Paskaleva I. Personal communication; 2016.

[43] Purcaru G. He Vrancea, Romania, earthquake of march 4, 1977 - a quite successful prediction. Phys Earth Planet Inter 1979;18:274-87.

[44] Radulian M, Mandrescu N, Panza GF, Popescu E, Utale A. Characterization of seismic zones in Romania. Pure Appl Geophys 2000;157:57-77.

[45] Radu C. Contribution a l'etude de la seismicite de la Romanie at comparaison avec la seismicite de sud-est de la France [Ph.D. Thesis]. Universite de Strasbourg; 1974. p. 404.

[46] Richter CF. Seismic Regionalization. Bull Seismol Soc Am 1959;49:123-62.

[47] Šalić B, Milutinović ZV, Garevski MD. Results achieved and improvements needed in the field of seismic hazard assessment of Republic of Macedonia, Proceedings 15 World Conference On Earthquake Enginering, Lisboa, Portugal; 2012.

[48] Telesca L, Alcaz V, Sandu I. Analysis of 1978-2008 crustal and sub-crustal earthquake catalog of Vrancea region. Nat Hazards Earth Syst Sci 2013;12:1321-5.

[49] Todorovska MI, Trifunac MD. The role of earthquake hazard maps in loss estimation: a Study of the Northridge Earthquake, discussion of paper by R.B. Olshansky. Earthq Spectra 1998;14(3):557-63.

[50] Todorovska MI, Trifunac MD. A Seismic Hazard Model for Peak Strains in Soils During Strong Earthquake Shaking. Earthq Eng Eng Vib 1996;16(Supplement):1-12.

[51] Todorovska MI, Trifunac MD. Hazard mapping of normalized peak strain in soil during earthquakes - microzonation of a metropolitan area. Soil Dyn Earthq Eng 1996;15(5):321-9.

[52] Todorovska MI, Trifunac MD. Liquefaction opportunity mapping via seismic wave energy. Geotech Geoenviron Eng ASCE 1999;125(12):1032-42.

[53] Todorovska MI, Gupta ID, Gupta VK, Lee VW, Trifunac MD. "Selected Topics in Probabilistic Seismic Hazard Analysis. Los Angeles, California: Dept. of Civil Eng. Report No. CE95-08, Univ. of Southern California; 1995.

[54] Todorovska MI, Lee VW, Trifunac MD. Shaking hazard compatible methodology for probabilistic assessment of permanent ground displacement across earthquake faults. Soil Dyn Earthq Eng 2007;27(6):586-97.

[55] Todorovska MI, Trifunac MD, Lee VW. Probabilistic Assessment of Permanent Ground Displacement Across Earthquake Faults, Proceedings of Earthquake Engineering in the 21st Century to mark 40th anniversary of IZIIS - Skopje, August 28-Sptember 1, 2005, Skopje and Ohrid, Macedonia; 2005.
[56] Todorovska MI, Trifunac MD, Ding H, Orbović N. Coherency of dispersed synthetic earthquake ground motion at small separation distances: dependence on site condition. Soil Dyn Earthq Eng 2015;79:253-64.

[57] Trifunac MD. Seismic Microzonation Mapping Via Uniform Risk Spectra, In: Proceedings of the 9th World Conference Earthquake Engineering, VII, 75-80, Tokyo-Kyoto, Japan; 1988.

[58] Trifunac MD. Threshold magnitudes, which exceed the expected ground motion during the next 50 years in a metropolitan area. Geofizika 1989;6:1-12.

[59] Trifunac MD. How to model amplification of strong earthquake ground motions by local soil \& geologic site conditions. Earthq Eng Struct Dyn 1990;19(6):833-46.

[60] Trifunac MD. 75th Anniversary of the Response Spectrum Method - A Historical Review. Soil Dyn Earthq Eng 2008;28(9):676-85. [2008].

[61] Trifunac MD. Schantz T, Iankov R, editors. The Nature of Site Response During Earthquakes, Proc. NATO ARW workshop in Borovec, 30 August - 3 September 2008, Bulgaria, published in Coupled Site and Soil-Structure Interaction effects with Applications to Seismic Risk Mitigation. B. V.: NATO Science for Piece and Security Series C: Environmental Security, 3-31, Springer Science + Business Media; 2008. [2009].

[62] Trifunac MD. Seismic Microzonation and Near-Field Effects, In: Proceedings of the 9th International Workshop on Seismic Microzoning and Risk Reduction (9IWSMRR), Cuernavaca, Morelos, Mexico, 21-24 February 2010.

[63] Trifunac MD. Earthquake response spectra for performance based design - A Critical Review. Soil Dyn Earthq Eng 2012;37(6):73-83.

[64] Trifunac MD. Site conditions and earthquake ground motion - a review. Soil Dyn Earthq Eng 2016;11(4):229-41.

[65] Trifunac MD, Brady AG. On the correlation of seismic intensity scales with the peaks of recording strong ground motion. Bull Seismol Soc Am 1975;90:88-100.

[66] Trifunac MD, Ivanović SS. Reocurrence of site specific response in Former Yugoslavia -part I: montenegro. Soil Dyn Earthq Eng 2003;23(8):637-61.

[67] Trifunac MD, Ivanović SS. Reoccurrence of site specific response in former Yugoslavia - Part II: friuli, Banja Luka and Kopaonik. Soil Dyn Earthq Eng 2003;23(8):663-81.

[68] Trifunac MD, Todorovska MI. Can aftershock studies predict site amplification? Northridge, CA, earthquake of 17 January 1994. Soil Dyn Earthq Eng 2000;19(4):233-51.

[69] Trifunac MD, Todorovska MI. Long period microtremors, microseisms and earthquake damage: northridge, CA, earthquake of 17 January 1994. Soil Dyn Earthq Engrg 2000;19(4):253-67.

[70] Trifunac MD, Hao TY, Todorovska MI. On reoccurrence of site specific response. Soil Dyn Earthq Engrg 1999;18(8):569-92.

[71] Udwadia FE, Trifunac MD. Characterization of response spectra through the statistics of oscillator response. Bull Seism Soc Am 1974;64(1):205-19.

[72] Wenzel F, Lorenz FP, Sperner B, Oncescu MC. Seismotectonics of the Romanian Vrancea Area, in Vrancea Earthquakes:Tectonics, Hazard and Risk Mitigation, (edited by Wenzel et al.), 15-25; 1999.

[73] Weichert DH. Estimation of the earthquake recurrence parameters for unequal observation periods for different magnitudes. Bull Seism Soc Am 1980;70:1337-46.

[74] Wells DL, Coppersmith JK. New empirical relations among magnitude, rupture width, rupture area, and surface displacement. Bull Seism Soc Am 1994;84:974-1002. 